\title{
Small Molecules Targeting the Specific Domains of Histone-Mark Readers in Cancer Therapy
}

\author{
Huihui Zhu ${ }^{1}$, Tao Wei ${ }^{1}$, Yong Cai ${ }^{1,2}$ and Jingji Jin ${ }^{1,2, * \mathbb{C}}$ \\ 1 School of Life Sciences, Jilin University, Changchun 130012, China; zhuhh15@mails.jlu.edu.cn (H.Z.); \\ taowei16@mails.jlu.edu.cn (T.W.); caiyong62@jlu.edu.cn (Y.C.) \\ 2 School of Pharmacy, Changchun University of Chinese Medicine, Changchun 130117, China \\ * Correspondence: jjjin@jlu.edu.cn; Tel.: +86-431-8515-5475
}

Academic Editors: Franco M. Buonaguro and Anna Lucia Tornesello

Received: 17 December 2019; Accepted: 22 January 2020; Published: 29 January 2020

\begin{abstract}
Epigenetic modifications (or epigenetic tags) on DNA and histones not only alter the chromatin structure, but also provide a recognition platform for subsequent protein recruitment and enable them to acquire executive instructions to carry out specific intracellular biological processes. In cells, different epigenetic-tags on DNA and histones are often recognized by the specific domains in proteins (readers), such as bromodomain (BRD), chromodomain (CHD), plant homeodomain (PHD), Tudor domain, Pro-Trp-Trp-Pro (PWWP) domain and malignant brain tumor (MBT) domain. Recent accumulating data reveal that abnormal intracellular histone modifications (histone marks) caused by tumors can be modulated by small molecule-mediated changes in the activity of the above domains, suggesting that small molecules targeting histone-mark reader domains may be the trend of new anticancer drug development. Here, we summarize the protein domains involved in histone-mark recognition, and introduce recent research findings about small molecules targeting histone-mark readers in cancer therapy.
\end{abstract}

Keywords: histone marks; histone acetylation; histone methylation; cancer therapy

\section{Introduction}

In eukaryotic cells, histone octamers and DNA together form the basic building block of the chromosome-the nucleosome. The N-terminal tails of the four histones involved in the formation of nucleosomes interact with the acidic patch on the neighboring nucleosomes to form nucleosomal arrays and can be modified by various chromatin-modifying enzymes [1]. Post-translational modifications (PTMs) of the N-terminal tails of histones, such as acetylation, methylation, phosphorylation and ubiquitination, can alter the chromatin structure through affecting the interaction between histones and DNA [2,3]. It is well known that the precise organization of chromatin is important for many intracellular biological processes including gene transcription and recombination [4]. On the other hand, histone marks provide a platform for subsequent protein recruitment [5]. A large number of research data have suggested that different histone marks can be specifically recognized by different proteins (readers). These readers often possess the special domains that recognize and bind to specific histone marks like acetyl-lysines, or identifying methylated lysines or methylated arginine residues. For example, methyl $\mathrm{CpG}$ binding domain (MBD) family combined with other factor bind to methylated DNA, which mediates certain genes silencing [6]. Given that abnormal regulation of histone marks is implicated in the occurrence of various diseases including cancer, therefore, it is not difficult to speculate that the functional regulation of the specific domains of histone-mark readers using small molecules may be the trend of new anticancer drug development. In this review, we focus on the histone-mark readers, summarize the recent research findings that link crosstalk between the domain of readers and histone marks, further discuss the effects of small molecules targeting to the specific 
domain of readers on tumor-epigenetics, and speculate on the potential role that may be relevant to cancer therapy.

\section{Proteins that Recognize Histone Modification Sites}

As the basic structural unit of chromatin, the nucleosome consists of 147 base pairs (bp) of DNA and a histone octamer, which contains two copies each of histones (H2A, H2B, H3 and H4) $[7,8]$. Histone marks on the $\mathrm{N}$-terminal tails of histones that extended beyond the nucleosome core structure can be regulated by different proteins (or complexes). It is worth mentioning that the histone mark on histone tails is a dynamic and reversible process [9]. Some proteins can add marks to the specific amino acid sites of histones just like writers, while others have roles to remove marks as erasers [10]. In addition, some proteins are recruited at the site of histone marks to obtain instructions for performing functions. However, whether it is to remove the marks or to recruit proteins to a specific modified site, it is usually necessary for the proteins to recognize the specific histone marks just like a reader [11]. Numerous studies have shown that histone-mark readers often recognize marks through the functional domain contained in itself: such as BRD, CHD, PHD and MBT domains. And these special functional domains determine the targeting of readers to different histone marks.

\subsection{Histone Acetylation Readers}

As one of the well-characterized PTMs, histone acetylation is dynamically regulated by histone acetyltransferases (HATs) and histone deacetylases (HDACs) [12-14]. Dynamic balance of intracellular acetylation status is involved in many important physiological processes such as gene transcription, cell cycle regulation, DNA replication, DNA damage repair, as well as chromosome remodeling [15]. Known histone-mark readers that can recognize histone acetylation are roughly classified into three categories, including BRD, double PHD finger (DPF) and YEATS domains [16].

\subsubsection{BRD-Containing Proteins}

BRD-containing proteins are ubiquitously expressed in most tissues and widely present in proteins with multiple catalytic and scaffold functions [17]. Structural analysis have clarified that BRDs contain evolutionarily conserved domains including a left-handed bundle of four $\alpha$-helices $(\alpha \mathrm{Z}, \alpha \mathrm{A}, \alpha \mathrm{B}$, $\alpha C)$, linked by ZA and BC loops, which determine binding specificity [18]. Based on sequence or structure similarity, human BRD-containing proteins are divided into eight families [19]. Many proteins with BRD belong to chromatin remodeling or modifying enzymes. As shown in Table 1, BRDs in HATs such as GCN5L2, PCAF, CREBBP act as a protein-protein interaction module that specifically recognize and bind to acetylated histones like H4K8ac, H4K16ac, H4K20ac, H3K14ac, and H3K36ac, thereby affecting subsequent intracellular biological functions [20-22]. While the MLL and ASH1L belong to methyltansferases (HMTs), that regulate transcription of genes by targeting H3K4me and H3K36me, respectively [23,24]. It has been reported that MLL-like proteins may target histone H4K16ac. For example, the MOF/NSL HAT complex, which can acetylate histone $\mathrm{H} 4 \mathrm{~K} 16 \mathrm{ac} / \mathrm{K} 5 \mathrm{ac} / \mathrm{K} 8 \mathrm{ac}$, functions in promoting histone H3K4me2 activity by MLL/SET complexes in a unidirectional manner [25], indicating that the MLL/SET complexes may only be recruited in H4K16ac/K5ac/K8ac enriched chromatin. 
Table 1. Human bromodomain family and its features.

\begin{tabular}{|c|c|c|c|c|c|}
\hline Groups & Proteins & Name & BRDs & Alias & Functions and Recognize Histones \\
\hline \multirow{5}{*}{ BRD I } & BAZ1A & $\begin{array}{l}\text { Bromodomain adjacent to zinc finger } \\
\text { domain, } 1 \mathrm{~A}\end{array}$ & 1 & ACF1, WALp1, WCRF180 & Chromatin remodeling factor [26] \\
\hline & BPTF & Fetal Alzheimer antigen & 1 & FALZ, FAC1 & Recognizes H4K16ac and H3K4me3 [27] \\
\hline & CECR2 & $\begin{array}{l}\text { Cat eye syndrome chromosome } \\
\text { region, candidate } 2\end{array}$ & 1 & KIAA1740 & Recognizes/binds to acetylated histones [18] \\
\hline & GCN5L2 & $\begin{array}{l}\text { General control of amino acid } \\
\text { synthesis 5-like } 2\end{array}$ & 1 & $\begin{array}{l}\text { GCN5, KAT2A, STAF97, } \\
\text { PCAF-B }\end{array}$ & $\begin{array}{l}\text { HAT, interact with EP300/CREBBP and ADA2; Binds to } \\
\text { H4K16ac }[20,22]\end{array}$ \\
\hline & PCAF & P300/CBP-associated factor & 1 & $\begin{array}{l}\text { CREBBP-associated factor, } \\
\text { KAT2B }\end{array}$ & $\begin{array}{l}\text { HAT, promotes transcriptional activation; Targets to H4K8ac, } \\
\text { H3K14ac and H3K36ac }[21,22]\end{array}$ \\
\hline \multirow{4}{*}{$\begin{array}{l}\text { BRD II } \\
\text { (BET) }\end{array}$} & BRD2 & Bromodomain-containing protein 2 & 2 & FSH, RING3 & $\begin{array}{l}\text { Associated with acetylated chromatin during mitosis; Binds to the } \\
\qquad \text { H4K5ac/K12ac and H3K14ac [28] }\end{array}$ \\
\hline & BRD3 & Bromodomain-containing protein 3 & 2 & ORFX, RING3L & $\begin{array}{l}\text { Transcriptional regulator; Binds to the H4K5ac/K12ac and } \\
\text { H3K14ac [28] }\end{array}$ \\
\hline & BRD4 & Bromodomain-containing protein 4 & 2 & CAP, MCAP, HUNK1 & $\begin{array}{l}\text { Interacts with acetylated H3K14 and H4K5/K8/K12/K16; Rerulates } \\
\text { H3K27ac and H3K56ac }[18,29]\end{array}$ \\
\hline & BRDT & $\begin{array}{l}\text { Bromodomain-containing protein, } \\
\text { testis specific }\end{array}$ & 2 & BRD6 & Chromatin remodeling factor; Recognizes H4K5ac/K8ac [30] \\
\hline \multirow{7}{*}{ BRD III } & BAZ1B & $\begin{array}{l}\text { Bromodomain adjacent to zinc finger } \\
\text { domain, } 1 \mathrm{~B}\end{array}$ & 1 & WSTF, WBSCR9 & $\begin{array}{l}\text { Chromatin remodeling factor, transcriptional regulator; Recognizes } \\
\text { H2BK12ac, H3K14ac and H4K16ac [31] }\end{array}$ \\
\hline & BRD8B & Bromodomain-containing protein $8 \mathrm{~B}$ & 2 & SMAP, SMAP2 & Transcriptional regulator [32] \\
\hline & BRWD3 & $\begin{array}{l}\text { Bromodomain-containing protein } \\
\text { disrupted in leukemia }\end{array}$ & 2 & BRODL & $\begin{array}{l}\text { Associated with translocations in patients with B-cell chronic } \\
\text { lymphocytic leukemia [33] }\end{array}$ \\
\hline & CREBBP & CREB Binding Protein & 1 & CBP, КАTЗА & HAT; Binds to H4K20ac [22] \\
\hline & EP300 & E1A-binding protein p300 & 1 & p300, KAT3B & HAT, acetylate H3K122/K27 and non-histone proteins $[34,35]$ \\
\hline & PHIP & $\begin{array}{c}\text { Pleckstrin homology } \\
\text { domain-interacting protein }\end{array}$ & 2 & $\begin{array}{l}\text { DR11, WDR11, SRT1, } \\
\text { HH14, BRWD2 }\end{array}$ & $\begin{array}{c}\text { Binds to the insulin receptor substrate 1; Regulates growth and } \\
\text { survival of pancreatic beta cells [36] }\end{array}$ \\
\hline & WDR9 & WD repeat domain 9 & 2 & BRWD1 & Chromatin remodeling factor [37] \\
\hline
\end{tabular}


Table 1. Cont

\begin{tabular}{|c|c|c|c|c|c|}
\hline Groups & Proteins & Name & BRDs & Alias & Functions and Recognize Histones \\
\hline \multirow{7}{*}{ BRD IV } & ATAD2 & Two AAA domain containing protein & 1 & ANCCA & Transcriptional regulator; Binds to $\mathrm{H} 3 \mathrm{~K} 14 \mathrm{ac}, \mathrm{H} 4 \mathrm{~K} 5 \mathrm{ac} / \mathrm{K} 12 \mathrm{ac}[38,39]$ \\
\hline & ATAD2B & KIAA1240 protein & 1 & KIAA1240 & Binds to acetylated chromatin [gene card] \\
\hline & BRD1 & Bromodomain-containing protein 1 & 1 & BRPF2 & $\begin{array}{l}\text { A subunit of the MOZ/MORF HAT complex, regulates } \\
\text { H3K14ac [40] }\end{array}$ \\
\hline & BRD7 & Bromodomain-containing protein 7 & 1 & BP75, NAG4, CELTIX1 & $\begin{array}{l}\text { Transcriptional regulator; Binds to acetylated H3K9/K14, } \\
\text { H4K8/K12/K16 [41] }\end{array}$ \\
\hline & BRD9 & Bromodomain-containing protein 9 & 1 & LAVS3040, PRO9856 & Chromatin remodeling; Recognizes H4K5ac/K8ac [42] \\
\hline & BRPF1 & $\begin{array}{l}\text { Bromodomain- and PHD } \\
\text { finger-containing protein 1A }\end{array}$ & 1 & BR140, Peregrin & $\begin{array}{l}\text { Transcriptional activator; Recognizes acetylated } \mathrm{H} 2 \mathrm{AK} 5 \text { and } \\
\text { H3K14, H4K5/K8/K12 [43] }\end{array}$ \\
\hline & BRPF3 & $\begin{array}{l}\text { Bromodomain- and PHD } \\
\text { finger-containing protein, } 3\end{array}$ & 1 & KIAA1286 & $\begin{array}{l}\text { Regulats replication origin activation and histone H3K14 } \\
\text { acetylation [44] }\end{array}$ \\
\hline \multirow{9}{*}{ BRD V } & BAZ2A & $\begin{array}{l}\text { Bromodomain adjacent to zinc finger } \\
\text { domain, } 2 \mathrm{~A}\end{array}$ & 1 & TIP5, WALp3 & Transcriptional repressor; Interacts with H4K16ac [45] \\
\hline & BAZ2B & $\begin{array}{l}\text { Bromodomain adjacent to zinc finger } \\
\text { domain, } 2 \mathrm{~B}\end{array}$ & 1 & WALp4 & Transcriptional regulator; Binds to H3K14ac [46] \\
\hline & SP100 & Nuclear antigen Sp100 & 1 & Lysp100b & $\begin{array}{l}\text { Binds heterochromatin and functions in immunity, and gene } \\
\text { regulation [47] }\end{array}$ \\
\hline & SP110 & Nuclear antigen Sp110 A, & 1 & IPR1, VODI, IFI41, IFI75 & Transcriptional activator [48] \\
\hline & SP140 & SP140 nuclear body protein & 1 & LYSP100 & $\begin{array}{l}\text { Associated with multiple sclerosis, Crohn's disease, chronic } \\
\text { lymphocytic }[49,50]\end{array}$ \\
\hline & SP140L & SP140 nuclear body protein like & 1 & SP140L-1 protein & Chromatin binding [gene card] \\
\hline & TRIM24 & Tripartite motif-containing 24 & 1 & TIF1a, PTC6, RNF82 & Transcriptional regulator; Recognizes H3K23ac [51] \\
\hline & TRIM33 & Tripartite motif-containing $33 \mathrm{~A}$ & 1 & PTC7, RFG7, TIF1g & Control transcriptional elongation; Recognizes H3K18ac/K23ac [52] \\
\hline & TRIM66 & Tripartite motif-containing 66 & 1 & TIF1d & Transcriptional repressor [53] \\
\hline
\end{tabular}


Table 1. Cont

\begin{tabular}{|c|c|c|c|c|c|}
\hline Groups & Proteins & Name & BRDs & Alias & Functions and Recognize Histones \\
\hline \multirow{2}{*}{ BRD VI } & MLL & $\begin{array}{c}\text { Myeloid/lymphoid or mixed } \\
\text { lineage leukemia }\end{array}$ & 1 & $\begin{array}{c}\text { HRX, TRX1, CXXC7, } \\
\text { ALL-1 }\end{array}$ & HMT, mediats H3K4me [23,25] \\
\hline & TRIM28 & Tripartite motif-containing 28 & 1 & KAP1, RNF96, TIF1b & $\begin{array}{l}\text { Transcriptional regulator; Regulates H3K9ac and H3K14ac } \\
\text { [gene card] }\end{array}$ \\
\hline \multirow{7}{*}{ BRD VII } & BRWD3 & & & & \\
\hline & PHIP & & & & \\
\hline & TAF1 & $\begin{array}{l}\text { TAF1 RNA polymerase II, TATA } \\
\text { box-binding protein } \\
\text { (TBP)-associated factor }\end{array}$ & 2 & $\begin{array}{l}\text { TAFII250, P250, CCG1, } \\
\text { TAF2A }\end{array}$ & Transcription inhibition; Binds to H4K5/K8/K12/K16ac [54] \\
\hline & TAF1L & $\begin{array}{l}\text { TAF1-like RNA polymerase II, TATA } \\
\text { box-binding protein } \\
\text { (TBP)-associated factor }\end{array}$ & 2 & TAF(II)210 & Functions as a TBP-associated factor [55] \\
\hline & WDR9 & & & & \\
\hline & ZMYND8 & $\begin{array}{l}\text { Zinc Finger MYND-Type } \\
\text { Containing } 8\end{array}$ & 1 & PRKCBP1, RACK7 & $\begin{array}{l}\text { Transcriptional regulator; Recognizes H4K5/K8/K12/K16/K20ac } \\
\text { H3K9ac, and H3K14ac [56] }\end{array}$ \\
\hline & ZMYND11 & remodeling factor containing 11 & 1 & BS69, BRAM1, MRD30 & Transcriptional repressor [57] \\
\hline \multirow{4}{*}{$\begin{array}{l}\text { BRD } \\
\text { VIII }\end{array}$} & ASH1L & ash1 (absent, small, or homeotic)-like & 1 & ASH1, KMT2H & HMT, methylates H3K36me2 [24] \\
\hline & PBRM1 & Polybromo 1 & 6 & PB1, BAF180 & $\begin{array}{l}\text { Chromatin remodeling factor; High-affinity with acetylated histone } \\
\qquad \text { H3 at lysine 4, 9, } 14 \text { and } 23 \text { [58] }\end{array}$ \\
\hline & SMARCA2 & $\begin{array}{c}\text { SWI/SNF-related matrix associated } \\
\text { actin-dependent regulator of } \\
\text { chromatin a } 2\end{array}$ & 1 & BRM, SNF2L2 & $\begin{array}{l}\text { Chromatin remodeling factor, Splicing regulator; Interact with and } \\
\text { moderate specificity for H3K14ac [59] }\end{array}$ \\
\hline & SMARCA4 & $\begin{array}{l}\text { SWI/SNF-related matrix associated } \\
\text { actin-dependent regulator of } \\
\text { chromatin a } 4\end{array}$ & 1 & BRG1, SNF2L4, SNF2LB & $\begin{array}{l}\text { Chromatin remodeling factor; Interact with and moderate } \\
\text { specificity for H3K14ac [59] }\end{array}$ \\
\hline
\end{tabular}


It is generally believed that acetylation of histones often causes loosened chromatin structure, increasing the accessibility of nucleosomal DNA to transcription factors, thereby activating gene transcription [60]. Just like BRD2 and BRD3 prefer to bind to the chromatin associated with active gene transcription, in which is enriched H4K5ac/K12ac and H3K14ac in human embryonic kidney 293 cells [28]. The BRD family VII member TAF1 facilitates the activation of gene transcription through specific binding to the acetylated histone H4K5/K8/K12/K16 [54]. Compared with TAF1, the BRD family IV member ATAD2 shows multiple functions: (i) Like other BRDs, ATAD2 specifically interacts with acetylated histone H3K14 and diacetylated H4K5/K12 [38,39]; (ii) Assists heterochromatin reassembly during replication through competitively inhibiting the histone deacetylase HDAC1 [38]; (iii) Acting as an E2F co-activator plays a role in E2F-dependent gene activation [39]. Sometimes, BRD proteins may direct the recruitment of chromatin remodeling complex. For example, BRPF1 recognizes acetylated histones (H2AK5ac, H3K14ac, H4K5ac/K8ac/ K12ac) and directs the recruitment of MOZ HAT complex to chromatin [43].

In cells, acetylation of histones often provides a platform for the recruitment of subsequent chromatin remodeling enzymes and collectively performs intracellular biological functions. For instance, BRD4 not only interacts with acetylated histone H3K14ac, H4K5ac/K8ac/K12ac/K16ac [18], but also mediates EP300 to facilitate H3K27ac and H3K56ac at pluripotent genes, and this interaction recruits chromatin remodeler Brg1 to change chromatin structure in embryonic stem cells [29]. In other case, BAZ1B can selectively recognize H2BK12ac, H3K14ac and H4K16ac, and this interaction is indispensable for ligand-induced transrepression of the $1 \alpha(\mathrm{OH})$ ase gene [31]. Furthermore, EP300 and CREBBP share several conserved regions including BRD, HAT domain and cysteine-histidine-rich regions, and function as transcriptional co-activator, playing a critical role in cell proliferation, cell cycle, as well as tumorigenesis [61]. Some BRD proteins can simultaneously recognize acetylation and methylation on histones. ZMYND8 is a good example. Based on the published data, ZMYND8 recognizes acetylated and methylated histones through its PHD/BRD/PWW reader cassette, thereby functions in assembling transcriptional complexes to recruit to DNA-damaged sites [56]. Another example, BRD family I protein BPTF with both BRD and PHD domains can recognize histone H4K16ac and $\mathrm{H} 3 \mathrm{~K} 4 \mathrm{me}$, results in formation of a specific tran- histone modification pattern at mononuleosome level [27]. In addition, the BRD of BAZ2A, a member of BRD family V, recognizes and binds to acetylated histone $\mathrm{H} 4 \mathrm{~K} 16$, which further recruit NoRC (nucleolar remodeling complex) to trigger deacetylation of histone $\mathrm{H} 4$ at K5/K8/K12 sites and NoRC-mediated heterochromatin formation [45].

Some tripartite motif-containing proteins such as TRIM24, TRIM 28, TRIM33 and TRIM66 are members of the human TRIM family also possess the functions in recognizing acetylated histones. For example, TRIM 24 interacts with histone H3K23ac to drive EGFR-mediated tumor growth [51]. TRIM33, a PHD finger-BRD containing protein, determines the binding of TRIM33 to acetylated histone H3K18/K23 while activating E3 ubiquitin ligase activity, and further inhibiting gene transcription [52]. It is worth noting that PBRM1 (Polybromo-1) as a subunit of the Polybromo, Brg1-associated factors (PBAF) chromatin remodeling complex shows high-affinity with acetylated histone $\mathrm{H} 3$ at lysine 4 , 9, 14 and 23 sites [58]. During mitosis, PBRM1 localizes PBAF to kinetochores through the direct interaction between its six tandem BRDs and acetylated histones [58]. Furthermore, SMARCA2 and SMARCA4 as members of the SWI/SNF chromatin remodeling family interact with DNA and H3K14ac simultaneously, thereby play a role in regulating BAF activity [59].

\subsubsection{PHD Finger Proteins}

The PHD finger contains a zinc-binding motif (50-80 amino acid residues) that appears in many chromatin-associated proteins [62]. Compared with the BRD-containing proteins, recognition ability of the PHD finger proteins is more flexible, which recognizes acetylated or unacetylated and methylated histones. For example, the PHD6 finger of MLL4 (KMT2D) and the PHD7 finger of paralogous MLL3 (KMT2C) selective target to H4K16ac and provide a direct functional association between MLL3/4 and MOF [63]. MOZ (KAT6A), MORF (KAT6B), DPF1, DPF2 and DPF3 are important DPF proteins that 
can bind to acetylated lysines [64]. Take MOZ as an example, it can localize to the promoter region of the HOXA9 gene, thereby facilitating H3K14ac around the HOXA9 promoter region and HOXA9 gene transcription [65]. Similarly, MORF binds to the N-terminal tail of histone H3 and shows the preference for K9ac and K14ac [66]. Moreover, fluorescence microscopy and co-immunoprecipitation experiments showed that the PHD1/2 fingers in MORF are required for interaction with H3K14ac in vivo and localization to chromatin forming nuclear speckles [66]. Members of neuron-specific chromatin remodeling complex (BAF) such as DPF2 and DPF3 have been identified to be involved in cancer and embryonic development, respectively. Interestingly, each subunit has a different ability to recognize specific lysine site acetylated histones. DPF2 represses myeloid differentiation in MOLM-13 cells through binding to H3K14ac and H4K16ac via bipartite binding pockets [67]. However, DPF3b interacts with multiple acetylated histones including H3K9ac/K14ac, H4K5ac/K8ac/K12ac/K16ac, and globally co-occurs with histone modifications and BRG1 genomic binding sites, suggesting that DPF3b may act as an anchor between modified histones and the BAF complex [68].

\subsubsection{YEATS Proteins}

The YEATS family comprises five proteins, Yaf9, ENL, AF9, Taf14, and Sas5. From yeast to human, the YEATS domain is evolutionarily conserved [69]. There are three YEATS domain-containing proteins in S. cerevisiae and four in humans. Members of the YEATS family are found to be related to chromatin-remodeling, histone modification, transcription regulation, and DNA repair [70]. In support of the functional importance, dysfunction of YEATS family proteins is often associated with human disease, even cancer. A case in point is AF9, which is the most frequent fusion partner of human MLL proteins caused by chromosome translocations in acute myeloid leukemia (AML) [71]. The recognition of H3K9ac by AF9 is required to recruit DOT1L to chromatin and subsequently deposit H3K79 methylation on target genes to activate transcription [72]. ENL is another YEATS protein relevant to AML. It co-localizes with H3K9ac and H3K27ac on the promoters of actively transcribed genes associated with leukemia, disrupting the linkage between ENL and histone acetylation, decreasing RNA polymerase II recruitment to ENL target genes, thereby results in the suppression of oncogenic gene expression [73]. Besides, the oncogenic gene GAS41, is frequently amplified in human gliomas and preferentially binds to diacetylated histone $\mathrm{H} 3$ peptides (H3K18acK27ac) over mono-acetylated histone $\mathrm{H} 3$ through a bivalent binding mode [74]. Except for human YEATS family proteins, yeast Taf14 contributes to the recognition of histone acetylation. Importantly, block the Taf14-H3K9ac interaction greatly impairs transcriptional regulation coordinated with Gcn 5 and sensitizes $S$. cerevisiae cells to DNA damage [75]. Interestingly, histone chaperone Asf1 in yeast is a structural homolog of the Yaf9, and recognizes H3K14ac. However, due to the lack of sequence similarity, it is not generally considered a YEATS protein [76].

\subsection{Histone Methylation Readers}

Another well-characterized PTM is a reversible histone methylation (mono-, di- tri-) which is controlled by histone methyltransferases and histone demethylases. The canonical methylated sites contain six lysine residues of histone H3 (K4, K9, K26, K27, K36 and K79), K20 of histone H4 and K26 of histone H1 [77]. These modifications on histone tails mediate widely biological processes, especially gene transcription and DNA damage response. In the past decades, a set of specific-domain containing methyl-lysine mark readers were identified, such as CHD, PHD finger, Tudor, PWWP motif, MBT and WD40 repeat (WDR) domains (Figure 1).

\subsubsection{Chromodomain Proteins}

The chromodomain (chromatin-organization-modifier domains) has been identified as a 30-70 amino acid residue protein module with a three-stranded $\beta$-sheet and an adjacent helix [78]. Chromodomain proteins form or maintain the condensed chromatin structures, and have been involved in transcriptional repression and genome stability [79]. Depending on the functional 
domain, chromodomain proteins are classified into the heterochromatin (HP1)/polycomb (Pc) family, chromo-ATPase/helicase-DNA-binding (CHD) family, chromobarrel domain family, and the chromodomain $Y$ chromosome (CDY) family [80].

Human HP1 homologs (CBX1, -3, -5) and the Pc homologs (CBX2, -4, -6, -7, -8) are well known as the CBX proteins. The structural and biophysical differences between human HP1 and Pc chromodomains have been uncovered that HP1 homologs possess a large electronegative peptide binding surface, whereas Pc homologs have a much more hydrophobic surface [81]. With the conserved structures, human HP1 family proteins play an important role in heterochromatin packaging and gene silencing such as Chp1, Chp2 and Swi6 in yeast, and show a strong preference for H3K9me mark [82,83]. Human Pc homologs exhibit a wide range of affinities for both H3K9me3 and H3K27me3 without a distinct preference [84]. Besides methylated histone lysine binding, certain Pc homologs are capable to bind to nucleic acids. For example, the CBX7-RNA interaction partly regulates the association of CBX7 with H3K9me3 and H3K27me3, and particularly impacts the inactive $\mathrm{X}$ chromosome [85].

The structure of chromobarrel domain is similar to that of the HP1/Pc chromodomain, but the chromobarrel domain has an extra $\beta$-sheet consisting of two additional strands [79]. Drosophila Msl3, human MRG15 and yeast Eaf3 are homologs with chromobarrel domain. Msl3, a subunit of male-specific lethal (MSL) complex, is required for the dosage compensation of X-linked genes, and specifically binds to the nucleosomes where is enriched with H3K36me3 or H4K20me1 [86,87], suggesting the methyl-lysine mediated DNA accessibility. Human MRG15 as an adaptor module bind to H3K36me2/3 peptides in a mode different from the canonical peptide binding mode in the $\mathrm{HP1/Pc}$ chromodomains [88]. Yeast Eaf3 protein is a member of the NuA4 histone acetylase and Rpd3 histone deacetylase complexes. Research data revealed that Eaf3 interacts with three states of methylated H3K36 (me1/2/3) and H3K4me3 marks. Binding of Eaf3 to H3K36me results in the preferential association of the Rpd3 complex, and further inhibiting transcriptional initiation within mRNA coding regions [89]. Another family with chromodomains is the CHD family that contains two $\mathrm{N}$-terminal tandem chromodomains and C-terminal helicase domains. Human CHD1 chromodomains possess secondary structures that are similar to HP1 family chromodomains [90], however, it shows different selectivity for H3K4me1/2/3. In HeLa cells, the interaction of CHD1 with H3K4me3 promotes the recruitment of transcriptional post-initiation and pre-mRNA splicing factors [91]. But in yeast, Chd1 does not bind to methylated H3K4 [92], suggesting the different preferences of CHD1 for histone marks in different species. In addition, human CHD7 directly binds to H3K4me which correlates with enhancer mediated transcription during development [93].

Human CDY family includes CDY, CDYL, and CDYL2. Recent reports confirm that the CDY is closely related to male infertility, which may connect to the interaction between CDY chromodomain and the H3K9me2/3 [94,95]. Multimerization of CDYL1b can read H3K9me3, and its association with $\mathrm{H} 3 \mathrm{~K} 9 \mathrm{me} 3$ is indispensable for the localization of CDYL1b to heterochromatin [96]. But mouse homolous Cdyl binds to not only H3K9me2/3 but also H3K27me3. Furthermore, the combination of $\mathrm{H} 3 \mathrm{~K} 9 \mathrm{me} 2$ and $\mathrm{H} 3 \mathrm{~K} 27 \mathrm{me} 3$ recruits $\mathrm{Cdyl}$ to $\mathrm{Xi}$, providing a specific binding platform, and facilitates propagation of the H3K9me2 modification by anchoring G9a in mESCs [97].

\subsubsection{PHD Finger Proteins}

PTMs on histone $\mathrm{H} 3 \mathrm{~N}$ - and $\mathrm{H} 4 \mathrm{C}$-terminal tails provide a perfect basis for histone PTM crosstalk. Despite the PHD fingers can be grouped into several major sub-families according to their binding targets, the PHD-proteins often display diverse histone PTM crosstalk sensitivity. Recent reports describe several examples. In one case, TAF3 as a member of the basal transcription complex (TFIID) directly binds to H3K4me3 and functions as a transcriptional coactivator in a PHD finger dependent manner, and further recruiting TFIID to the same histone marks via the TAF3 PHD finger [98]. Interestingly, asymmetric H3R2me2 can specifically inhibit TFIID binding to the tri-methylated H3K4, in contrast, H3K9ac and H3K14ac promote the interaction between TFIID and H3K4me3 [98]. In lung cancer cells, the interaction between PHF20 and H3K4me2 was disrupted by mutating PHD finger of 
PHF20, it further reduced MOF mediated H4K16ac targeting gene activation, as well as the preference of PHF20-Tudor2 for p53 dimethylation, suggesting the involvement of PHD finger in anti-cancer processes [99]. In another case, the connection of MLL5 PHD finger with H3K4me3 recruit MLL5 to actively transcribed genes and this association can be disrupted by phosphorylating H3T3 and H3T6, thereby leading to releasing MLL5 from chromatin during mitosis [100].

Histone $\mathrm{H} 3 \mathrm{~K} 4 \mathrm{me}$ is the major modification recognized by PHD fingers and it mediates various intracellular functions, whereas, minority PHD fingers have been found to bear towards H3K9me3 and H3K36me. Some PHD fingers are evolved with fine-tuned residue composition which integrated or paired with other reader domains, show various readerships. For example, a critical epigenetic remodeler UHRF1 contains multiple domains including Tandem Tudor Domain (TTD)-, PHD-, SRA (SET and RING associated)-, ubiquitin-like- and RING- domains. The PHD finger of UHRF1 preferentially interacts with unmodified H3 N-terminal tail, whereas the TTD cooperates with the PHD finger to specifically bind to H3K9me3 mark during the cell cycle in mammalian cells [101]. Another multi-domain containing protein CHD4 contains two PHD fingers, two chromodomains, and a nucleosome remodeling ATPase domain. Among them, PHD1 recognizes unmodified H3K4, H3K4me3, and H3K9me3, while PHD2 is easier to affinity with unmodified H3K4 and H3K9me3 [102]. Likewise, both PHF8 and JHDM1D are demethylases that can harbor a PHD binding to H3K4me3. Interestingly, the contact of PHF8-H3K4me3 enhances the demethylation activity on H3K9me2, in contrast, JHDM1D-H3K4me3 interaction inhibits the demethylation activity on H3K9me2 [103].

\subsubsection{Tudor Domain Proteins}

Tudor domain contains approximately sixty amino acids that are composed of 5 stranded $\beta$-barrel fold with one or two helices packed against the parallel $\beta$-sheet [104]. Tudor domain-containing proteins binding to methylated lysine or arginine residues function as molecular adaptors in differentiation, cell division, gametogenesis, and genome stability. Both PHF1 and PHF19 contain a single Tudor motif, a C-terminal chromo-like domain, and two PHD fingers. Based on recent research data, both PHF1 and PHF19 can selectively read H3K36me2/3 modification, and the interaction between PHF proteins and H3K36me inhibits the catalyzation activity of HMT PRC2 (Polycomb repressive complex 2) to facilitate the silencing of transcribed genes in human cancer cells and embryonic stem cells [105-107]. In addition, PHF1 regulates the deposition of the repressive H3K27me3 mark and functions as a cofactor in the PARP1- and Ku70-Ku80-initiated DNA damage response [106]. Some proteins contain two five-stranded $\beta$-barrels connected by a short (3-5 aa) linker termed TTD [108]. Just like JMJD2 family members JMJD2A, JMJD2B, and JMJD2C possess TTD domain, and are capable of removing tri-/di-methylation marks on H3K9 and H3K36 [109]. Structural analysis further shows that the JMJD2A-TTD recognizes H3K4me3 and H4K20me3 through which forms a bilobal, saddle-shaped structure, with each hybrid lobe resembling a canonical Tudor fold, indicating a role in chromatin-targeting [110,111]. In cells, TTD in JMDJ2A together with 53BP1 forms two independent folded structures, interacting with H4K20me2, thereby contributing to the accumulation of 53BP1 to sites of IR-induced DNA DSBs [112,113].

\subsubsection{PWWP Motif Proteins}

The PWWP domain, with a conserved Pro-Trp-Trp-Pro motif, consists of a five-stranded $\beta$-sheet packed against a variable helical bundle [108]. According to the literature, PWWP domain proteins possess methyl-lysine recognition activity like H3K36me3, H3K79me3, H4K20me3 and other histone modifications. Fluorescence polarization assay confirms that hepatoma-derived growth factor (HDGF) with highly conserved PWWP motif binds to methylated H3K36, H3K79 and H4K20 [114]. Another example is that the transcription elongation factor TbTFIIS2-2 can also read H4K17me3 and H3K32me3 marks via the conserved aromatic cage of the PWWP domain in its N-terminal [115]. Both PWWP domain containing proteins LEDGF (chromatin-associated protein PSIP1) and ZMYND11 selectively recognizes H3K36me3 and functions in alternative or RNA splicing [116,117]. In addition, LEDGF is essential for MLL-rearranged leukemia [118], and plays a key role in the HIV life cycle [119]. 
Furthermore, LEDGF interacts with other factors through unstructured regions that can be blocked by inhibiting serine/threonine kinases [120]. Hence it is a particularly interesting H3K36me3 reader for many diseases, and some of its interactions can be targeted by repurposing non-chromatin drugs. In yeast, a PWWP domain-containing protein Pdp3 recruits NuA3 HAT to chromatin through Pdp3 binding to H3K36me3, and coordinating transcriptional elongation at coding region [121,122]. However, a mutation in the PWWP motif of DNA methyltransferase DNMT3A abrogates its interaction with H3K36me2/3, and results in postnatal growth deficiency in mice [123], suggesting the importance of PWWP domain in biological functions. Moreover, the PWWP domain containing protein Pdp1 binds to the methylated histone H4K20 and DNA simultaneously, thereby regulates the catalysis activity of Set9 enzyme to regulate the methylation status of H4K20 by specifically recognizing H4K20me mark [124]. Although the existence of H4K20me3 does not impact on Pdp1-PWWP domain binding to DNA, the DNA binding activity may provide the energy to the PWWP domain to recognize the methylated-nucleosome. This coordinative function is essential for intracellular biological processes. Also, in vivo experiments have verified that the hepatocellular carcinoma pathogenesis associated protein HRP3 recognizes H3K36me2/3 marks and dsDNA, simultaneously, and plays a key role in recruiting HRP3 to the chromatin [125], suggesting that the PWWP binds histone and DNA with different binding pockets.

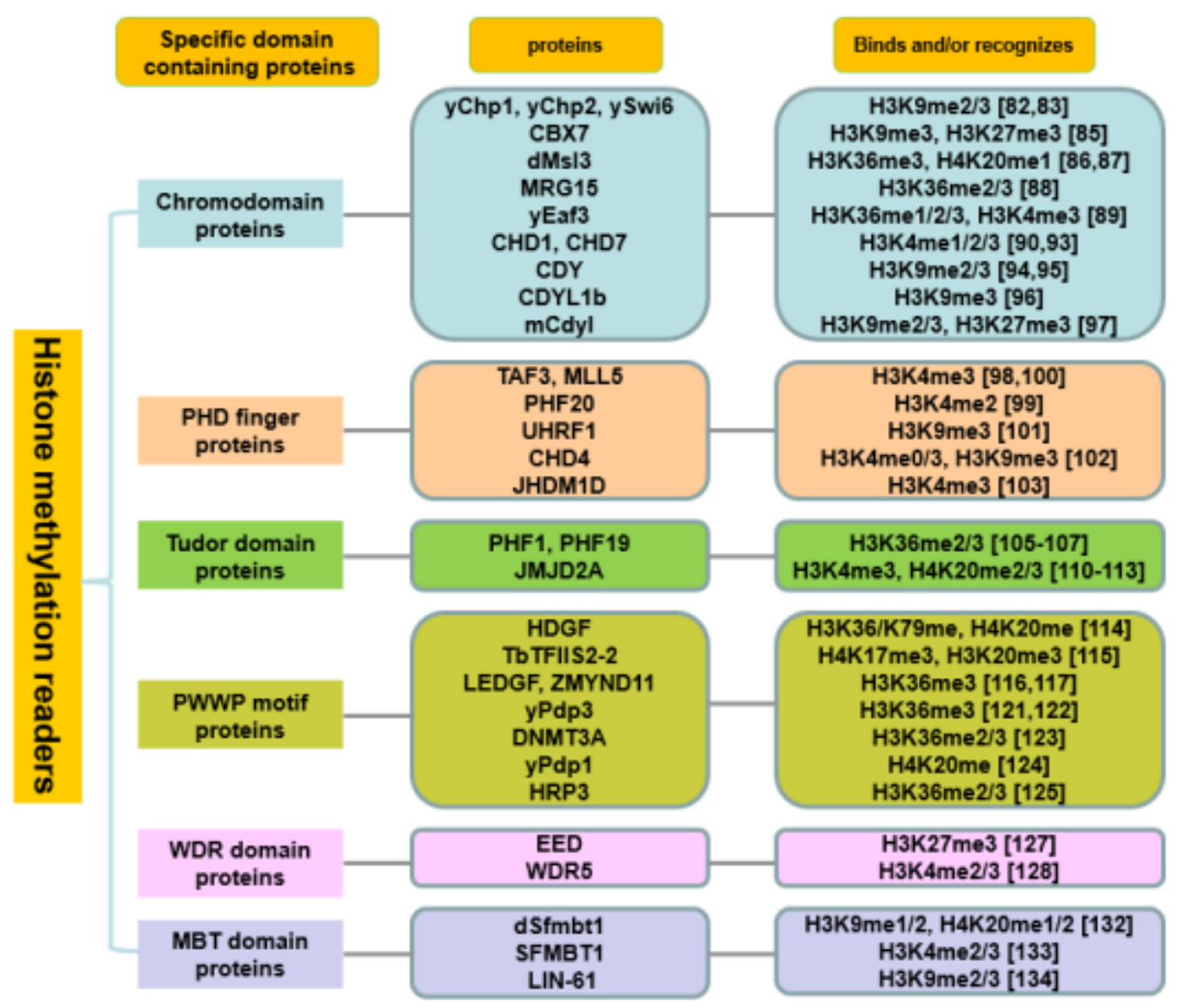

Figure 1. Histone methylation readers.

\subsubsection{WDR and MBT Domain Proteins}

The WDR domain is typically a seven-bladed $\beta$-propeller domain with an overall doughnut shape which is involved in a broad range of cellular pathways including ubiquitin- and immunerelated pathways, DNA damage response, cell cycle and chromatin remodeling [126]. The WDR domain-containing protein EED as a subunit of the PRC2 complex binds to H3K27me3 to enhance 
H3K27me3 activity of the catalytic subunit EZH2 [127]. Joanna et al. found that WDR5 directly and specifically associated with H3K4me2/3, and this interaction is essential for global H3K4me3 and HOX gene activation in human cells [128]. Furthermore, the structural analysis revealed that WDR5 cannot read out the methylation state of H3K4 directly. Instead, it presents the H3K4 side chain for further methylation by SET1 family proteins [129].

The MBT domain is highly conserved from C. elegans to humans that selectively recognizes and binds to methylated histones $[130,131]$. Drosophila Sfmbt1, a subunit of histone demethylase LSD1 complex, contains four MBT repeats and functions in HOX gene silencing through binding to $\mathrm{H} 3 \mathrm{~K} 9 \mathrm{me} 1 / 2$ and H4K20me1/2 [132]. Unlike the protein in Drosophila, human SFMBT1 recognizes histone H3K4me2/3 and these modifications are required for LSD1 recruitment to chromatin, H3K4 demethylation, and TGF $\beta$-induced epithelial to mesenchymal transition [133]. In C. elegans, the MBT-containing protein LIN-61 specifically interacts with $\mathrm{H} 3 \mathrm{~K} 9 \mathrm{me} 2 / 3$ and functions in the synthetic multivulval (synMuv) pathway of vulva development [134].

\section{Domain-Specific Inhibitors that Target Histone-Mark Readers}

Imbalanced global histone marks in cells have been involved in initiating events of cancer by aberrant regulating oncogenes and/or tumor suppressors [135]. Given that the histone marks on histone residues are the reversible processes, the roles of histone-mark readers in restoring the abnormal histone modifications to normal can be speculated. Therefore, small molecules that target the specific domains of -histone-mark readers have the potential to reverse abnormal gene expression during tumorigenesis, thus providing a new way to develop cancer therapeutic drugs. Previous literature well reviewed the chemical biology tools including selective PROTAC E3 ubiquitin ligase degraders, degrons, fluorescent ligands, dimerizers inhibitors, and other drugs. These small molecules can control the activities of deregulated epigenetic modulators, thereby changing intracellular biological processes [136]. In this section, we summarized domain-specific inhibitors that targeting histone-mark readers. The good news is that some small-molecule compounds have already begun trial use in the clinic.

\subsection{BET/BRD Inhibitors}

BRD domains have been identified in nuclear proteins including HATs, HMTs, chromatin remodeling enzymes and transcriptional co-activators. As mentioned earlier, the BRDs as the readers of acetyl marks on histone tails play a key role in gene transcriptional activation through targeting acetylated chromatin. Because of this, people have long set their sights on the development of small molecules that target BRDs in an attempt to achieve the purpose of treating cancer. According to the structural features of BRDs, the 'WPF shelf 'and 'gatekeeper' residue have been considered as two important specificity determinants of BRD inhibitors. The two residues of 'WPF shelf' change in hydrophobicity, size, or effects on backbone conformational properties, while 'gatekeeper' residue determines the shape of the entrance into the acetylation binding site [137]. These differences make the two areas be explored to achieve selectivity depending on the desired targets. Currently, several small molecules (BRDs inhibitors) that target the acetyl-binding pockets of the BRD or BRD-extraterminal proteins (BETs) have been developed. Some inhibitors like benzodiazepines and quinolines have been shown to have significant anti-proliferative activity against a variety of hematologic- and solid- tumors [138]. For example, the benzodiazepine JQ1 as a cell permeable small molecule can competitively bind to BRDs with high potency and specificity. A large number of studies have showed the efficacy of JQ1 in hematological malignancies and in a variety of solid tumors including glioblastoma neuroblastoma, breast cancer, pancreatic cancer, and lung cancer by repressing of c-MYC, FOSL1, or other transcriptional targets [139-143]. The quinolone class of BET inhibitors I-BET151 and I-BET-762 induce apoptosis and cell cycle arrest through down-regulation of MYC and up-regulation of HEXIM1 [144]. Recently, more BET inhibitors have been developed such as MK-8628 and PF-1. In mouse glioblastoma cells, MK-8628 (OTX015) showed much higher anti-proliferative effect than JQ1 [145]. PF-1 as an acetyl-lysine (Kac) mimetic inhibitor occupies the acetyl-lysine binding site in 
BRD2 and BRD4, thereby blocking the interaction of BET bromodomains with acetylated histone tails, and results in arrest of the cell cycle in G1, down-regulation of MYC, Aurora B kinase, and apoptosis induction [146]. There are similar BET inhibitors such as BMS-986158 and PLX-51107 which can also bind to the acetyl-lysine binding site in the BRD of BET proteins and disrupt the interaction between BET proteins and acetylated histones, thereby preventing the expression of certain growth-promoting genes, resulting in an inhibition of tumor cell growth [147]. Recent research data reveal that bromosporine, an innovative BET inhibitor, acts as a broad-spectrum BRD inhibitor has been confirmed to enhance 5-FU effect in colorectal cells under laboratory studies [148].

The most delighted thing is that a number of BET inhibitors such as RVX-208 (RVX00022), I-BET762 (GSK525762), FT-1101, CPI-0610, BAY1238097, INCB054329, TEN-010, GSK2820151, ZEN003694, BMS-986158, BI 894999, ABBV-075, GS-5829, PLX51107 and OTX015 (MK-8628) have been under clinical trials to investigate numerous cancer types or other diseases (Table 2). atherosclerosis, coronary syndromes and Alzheimer disease [149-153].

Table 2. BET inhibitors used in clinical trials (from clinicaltrials.gov as of September 2019).

\begin{tabular}{|c|c|c|c|}
\hline Compounds & Conditions & Status & $\begin{array}{l}\text { Clinical Trials } \\
\text { Identifier }\end{array}$ \\
\hline ABBV-075 & $\begin{array}{c}\text { AML; Advanced Cancer; Breast Cancer; } \\
\text { Multiple Myeloma; NHL; NSCLC; } \\
\text { Prostate Cancer }\end{array}$ & Completed Phase 1 & NCT02391480 \\
\hline BAY1238097 & Neoplasms & Terminated Phase 1 & NCT02369029 \\
\hline BI 894999 & Neoplasms & Recruiting Phase 1 & NCT02516553 \\
\hline \multirow{2}{*}{ BMS-986158 } & Advanced Tumors & Recruiting Phase $1 / 2$ & NCT02419417 \\
\hline & $\begin{array}{l}\text { Childhood Solid Tumor; Lymphoma; } \\
\text { Pediatric Brain Tumor }\end{array}$ & Recruiting Phase 1 & NCT03936465 \\
\hline \multirow{4}{*}{ CPI-0610 } & AML; Myelofibrosis; MMN; MS & Recruiting Phase $1 / 2$ & NCT02158858 \\
\hline & Lymphoma & Completed Phase 1 & NCT01949883 \\
\hline & Multiple Myeloma & Completed Phase 1 & NCT02157636 \\
\hline & Peripheral Nerve Tumors & Withdrawn Phase 2 & NCT02986919 \\
\hline FT-1101 & $\begin{array}{c}\text { AML; Acute Myelogenous Leukemia; } \\
\text { MS; NHL }\end{array}$ & Completed Phase 1 & NCT02543879 \\
\hline \multirow{3}{*}{ GS-5829 } & $\begin{array}{l}\text { Advanced Estrogen Receptor; } \\
\text { Positive HER2-Breast Cancer }\end{array}$ & Terminated Phase $1 / 2$ & NCT02983604 \\
\hline & Lymphomas, Solid Tumors & Completed Phase 1 & NCT02392611 \\
\hline & Metastatic CRPC & $\begin{array}{l}\text { Active, not recruiting } \\
\text { Phase } 1 / 2\end{array}$ & NCT02607228 \\
\hline GSK2820151 & Solid Tumors & Active, not recruiting Phase 1 & NCT02630251 \\
\hline \multirow{8}{*}{$\begin{array}{r}\text { GSK525762 } \\
\text { (I-BET762) }\end{array}$} & $\begin{array}{c}\text { Advanced and Retractory Solid Tumors; } \\
\text { Lympnomas }\end{array}$ & Active, not recruiting Phase1 & NCT03925428 \\
\hline & Carcinoma Midline & Active, not recruiting Phase 1 & NCT01587703 \\
\hline & Drug Interactions & Completed Phase 1 & NCT02706535 \\
\hline & Neoplasms & Recruiting Phase 2 & NCT01943851 \\
\hline & Neoplasms in combination with fulvestrant & Recruiting Phase 2 & NCT02964507 \\
\hline & Solid Tumors & Recruiting Phase 1 & NCT03150056 \\
\hline & Solid Tumours & Withdrawn Phase 2 & NCT03266159 \\
\hline & Solid Tumours & Available & NCT03702036 \\
\hline
\end{tabular}


Table 2. Cont.

\begin{tabular}{|c|c|c|c|}
\hline Compounds & Conditions & Status & $\begin{array}{l}\text { Clinical Trials } \\
\text { Identifier }\end{array}$ \\
\hline INCB054329 & Hematologic Malignancy; Solid Tumors & Terminated Phase $1 / 2$ & NCT02431260 \\
\hline \multirow{6}{*}{$\begin{array}{l}\text { MK-8628 } \\
\text { (OTX015) }\end{array}$} & AML & Active, not recruiting Phase 1 & NCT02698189 \\
\hline & AML & Withdrawn Phase $1 / 2$ & NCT02303782 \\
\hline & $\begin{array}{c}\text { Acute Lymphoblastic Leukemia; AML; } \\
\text { Diffuse Large B-cell Lymphoma; } \\
\text { Multiple Myeloma }\end{array}$ & Completed Phase 1 & NCT01713582 \\
\hline & Glioblastoma multiforme & Terminated Phase 2 & NCT02296476 \\
\hline & $\begin{array}{l}\text { CRPC; NUT Midline Carcinoma; NSCLC; } \\
\text { Triple Negative Breast Cancer }\end{array}$ & Terminated Phase 1 & NCT02698176 \\
\hline & $\begin{array}{c}\text { CRPC; NUT Midline Carcinoma; NSCLC } \\
\text { With Rearranged; ALK Gene/Fusion Protein } \\
\text { or KRAS Mutation; Pancreatic Ductal } \\
\text { Adenocarcinoma;Triple Negative } \\
\text { Breast Cancer } \\
\end{array}$ & Completed Phase 1 & NCT02259114 \\
\hline \multirow[b]{2}{*}{ PLX51107 } & AML; MS; NHL; Solid Tumors & Terminated Phase 1 & NCT02683395 \\
\hline & $\begin{array}{c}\text { AML; MS; MMN; } \\
\text { Myeloproliferative Neoplasm }\end{array}$ & $\begin{array}{l}\text { Not yet recruiting } \\
\text { Phase } 1\end{array}$ & NCT04022785 \\
\hline \multirow[b]{2}{*}{ RVX000222 } & Fabry Disease & Not yet recruiting Phase $1 / 2$ & NCT03228940 \\
\hline & $\begin{array}{l}\text { Cardiovascular Diseases; Coronary Artery } \\
\text { Disease; Type } 2 \text { Diabetes Mellitus }\end{array}$ & Active, not recruiting Phase 3 & NCT02586155 \\
\hline \multirow{3}{*}{$\begin{array}{c}\text { TEN-010 } \\
(\text { RO6870810) }\end{array}$} & Advances solid malignancies; Solid Tumors & Completed Phase 1 & NCT01987362 \\
\hline & AML; Myelodysplastic Syndromes & Completed Phase 1 & NCT02308761 \\
\hline & Multiple Myeloma & Active, not recruiting Phase 1 & NCT03068351 \\
\hline \multirow[b]{2}{*}{ ZEN003694 } & Metastatic CRPC & Completed Phase 1 & NCT02705469 \\
\hline & $\begin{array}{l}\text { Metastatic CRPC in combination } \\
\text { with Enzalutamide }\end{array}$ & $\begin{array}{c}\text { Active, not recruiting } \\
\text { Phase } 1 / 2\end{array}$ & NCT02711956 \\
\hline
\end{tabular}

AML, Acute Myeloid Leukemia; NSCLC, Non-Small Cell Lung Cancer; NHL, Non-Hodgkins Lymphoma; MS, Myelodysplastic Syndrome; MMN, Myelodysplastic/Myeloproliferative Neoplasm; CRPC, Castrate-resistant

Prostate Cancer.

For example, ZEN003694, GS-5829 and OTX015 are currently underway in clinical trials to treat castration-resistant prostate cancer. Recent developed BI 894999, FT-1101 and CPI-0610 are undergoing clinical trials in hematological cancers. BAY1238097, I-BET762, INCB054329, BMS-986158, ABBV-075 and PLX51107 are being clinically tested for several types of cancer. While the TEN-010 and GSK2820151 are being tested to treat solid tumors or hematological cancers, respectively. Some BET inhibitors are also used to treat human diseases other than cancer. RVX-208 (RVX00022), a BET inhibitor with preferred binding to the second bromodomains (BD2s) of BRD2 and BRD3, is currently being investigated in several clinical trials for cardiovascular diseases.

In recent years, with the deepening of epigenetics research, it has been found that in many cases the recognition of histone marks needs to be accomplished through non-BET functional domains. Given that many proteins with BRD belong to chromatin remodeling or modifying enzymes, the inhibitors of non-BET may achieve the purpose of treating cancer through correcting the epigenetic modification abnormalities caused by cancer. Several small molecules (I-BRD9, BI-7273/BI-9564, BI-7271/BI-7189, PFI-3, MS2126/MS7972, SGC-CBP30, PF-CBP1 and I-CBP112) as the BRD inhibitors have been reported [154]. Although the above small molecules are rarely used in clinical trials, some compounds have been clarified to have effects on several cancer cells in laboratory studies. For example, I-BRD9 may be used to identify downstream genes of BRD9 involved in oncology and immune response pathways in Kasumi-1 cells [155]. In addition, compounds BI-7273/BI-9564/ 
BI-7271/BI-7189 as inhibitors of BRD9 selectively suppress the proliferation of mouse and human AML cells $[156,157]$. Some non-BET inhibitors like MS2126/MS7972 target the transcriptional co-activators CREBBP and EP300, and result in the low level of p53 phosphorylation at Ser15 and acetylation at Lys382 via inhibiting the interaction of CREBBP and P53 in DNA damage response [158]. Subsequently, three chemical compounds including SGC-CBP30, PF-CBP1, and I-CBP112 were generated with higher potency and selectivity, showing anti-cancer effects on multiple myeloma and prostate cancer $[159,160]$. Fortunately, a p300/CBP BRD inhibitor CCS1477 is underway in clinical trials for treat metastatic prostate cancer and other solid tumours [161].

\subsection{PHD Inhibitors}

As mentioned earlier, the PHD finger is a versatile reader of histone marks that can selectively recognize unmethylated, methylated, and acetylated lysine residues [162]. Compared with BRD inhibitors, less attention has been focused on other functional domains such as PHD, and most of them are still in the preclinical stage. Based on research data, there are two modes of histone-mark recognition of PHD fingers, the cavity insertion and surface groove [163], and these two modes are commonly seen in readers with PHD fingers and chromodomains, as well as MBT domains and the Tudor domain 53BP1, respectively [164]. Because of the high conservation of the binding areas, the usage of secondary pockets is the strategy of choice to achieve the specificity [165]. Therefore, the development of PHD inhibitors has focused on the molecules that can selectively bind to cavity insertion and surface groove to attenuate or eliminate the ability of PHD to recognize the histone marks. For example, small molecule macrocyclic calixarenes can disrupt binding of ING2 PHD to methylated H3K4 in vivo and in vitro [166]. Furthermore, small molecules including disulfiram, amiodarone and tegaserod were identified as inhibitors of the interaction between JARID1A PHD3 and H3K4me3 using Halo Tag assay [167]. Shortly, fragment-based NMR screening approach discovered a small molecule benzimidazole that can selectively dock into the methylated H3K4 and displace the native H3K4me peptide from PHD finger of the Pygo-BCL9 chromatin reader [168].

\subsection{BMT and Tudor Inhibitors}

Chromatin-binding domain BMT recognizes methylated histone H3K4. Usually, the narrow aromatic cage pocket of MBT domain only allows lysine Kme1 and Kme2 bound, and results in repression of gene expression that involved in several disease states $[130,169]$. Although there is currently little known on the therapeutic effects of MBT domain inhibitors on clinical diseases, several compounds have been developed as the potent and selective inhibitors for MBT-domain proteins. For example, UNC669 and UNC926 are reported as the first inhibitors for L3MBTL1 [170,171], while the UNC1215, UNC1079, UNC1679, UNC56 and UNC2533 are discovered as the inhibitors for L3MBTL3 [164,172]. Some inhibitors like UNC1215 have revealed a regulatory function on apoptosis related protein BCLAF1 during DNA damage repair through interacting with L3MBTL3 [172] Further research found that some small UNC compounds can also be used as inhibitors of Tudor domain. It has been known that proteins with Tudor domains such as UHRF1, JMJD2A and 53BP1 play a critical role in cells as 'methyl-mark' readers. A small molecule UNC2170 inhibits 53BP1 binding at the interface of two Tudor domains of a 53BP1 dimer, showing cellular activity by suppressing class switch recombination [173]. Recent research shows that the clinically used iron chelator deferasirox potently inhibit JMJD2A, leading to a high level of histone trimethylation and inhibition of cancer cell growth [174]. What is more, UHRF1 inhibitors as an alternative of DNA demethylation agents can inhibit DNA methylation in cancer therapies [175].

\subsection{CHD Inhibitors}

CHD domains are a family of methyl-mark readers. HP1 and Pc family that typically bind to H3K9me3 and H3K27me3, respectively, are the most thoroughly studied CHD families. As mentioned earlier, the human paralogs of HP1 and Pc (chromobox, CBX proteins) are divided into eight CBX 
proteins, with $\mathrm{CBX} 1 / 3 / 5$ belonging to the HP1 family and $\mathrm{CBX} 2 / 4 / 6 / 7 / 8$ to the polycomb family. According to the cell experiments, each $\mathrm{CBX}$ protein has distinct roles at different stages of various aggressive cancers $[176,177]$. Recently, CBX7 and CBX8 have emerged as a potential therapeutic target for lymphoma, hepatocellular carcinoma, leukemia and breast cancer [177-180]. Therefore, small molecule CHD inhibitors target CBX7 and CBX8 are studied. MS37452 was developed as a selective ligand for CHD of CBX7. In PC3 prostate cancer cells, MS37452 reduced CBX7 occupancy at INK4A/ARE, showing transcriptional de-repression of gene products p14/ARE and p16/INK4a [181]. Another small molecule is the SW2_110A, a selective and cell-permeable inhibitor of the CBX8. It has been reported that SW2_110A specifically inhibits the proliferation of THP1 leukemia cells driven by MLL-AF9 translocation, resulting in significant decreased expression of MLL-AF9 target genes [182]. The small molecule UCN3866 was confirmed as a potent antagonist of the methyl-tag readers such as polycomb CBX and CDY families of CHDs, and can inhibit PC3 prostate cancer cell proliferation through down-regulating transcription of the INK4a/ARE locus [183].

\section{Conclusions and Perspectives}

It is clear that histone-mark reader proteins play an important role in basic biological processes in cells. Importantly, the different functional domains on these readers recognize different histone marks based on their specific binding pocket. After years of efforts, although there are many small molecule compounds developed to disrupt the interaction between specific domains and epigenetic-tags, few compounds can be used in clinical trial to treat cancers. Given that cancers may be caused by multiple factors such as the changes of cell microenvironment, imbalanced intracellular histone marks, the dysfunction of histone-mark readers and dis-coordinative function between different epigenetic mechanisms, etc. Therefore, the development of effective, multi-target small molecule compounds may be the key to uncover the cross-talk between histone-mark readers and histones, along with non-histone proteins. It will continue to attract more attention of researchers to develop better inhibitors in cancer therapy.

Author Contributions: H.Z., T.W., Y.C. and J.J. participated in writing, editing and making figures. All authors read and approved the final manuscript.

Funding: This research was funded by the National Natural Science Foundation of China, grant number [31571316 \& 31771421].

Conflicts of Interest: The authors declare no conflict of interest.

\section{Abbreviations}

BRD, bromodomain; CHD, chromodomain; PHD, plant homeodomain; PWWP, Pro-Trp-Trp-Pro; MBT, malignant brain tumor; PTMs, post-translational modifications; MBD, methyl CpG binding domain; HATs, histone acetyltransferases; HDACs, histone deacetylases; DPF, double PHD finger; HMTs, histone methyltansferases; PBRM1, Polybromo-1; PBAF, Polybromo, Brg1-associated factors; AML, acute myeloid leukemia; WDR, WD40 repeat; CDY, chromodomain Y chromosome; TTD, Tandem Tudor Domain; PRC2, Polycomb repressive complex 2; LEDGF, chromatin-associated protein PSIP1.

\section{References}

1. Azad, G.K.; Tomar, R.S. Proteolytic clipping of histone tails: The emerging role of histone proteases in regulation of various biological processes. Mol. Biol. Rep. 2014, 41, 2717-2730. [CrossRef]

2. Turner, B.M. Reading signals on the nucleosome with a new nomenclature for modified histones. Nat. Struct. Mol. Biol. 2005, 12, 110-112. [CrossRef]

3. North, J.A.; Šimon, M.; Ferdinand, M.B.; Shoffner, M.A.; Picking, J.W.; Howard, C.J.; Mooney, A.M.; van Noort, J.; Poirier, M.G.; Ottesen, J.J. Histone H3 phosphorylation near the nucleosome dyad alters chromatin structure. Nucleic Acids. Res. 2014, 42, 4922-4933. [CrossRef]

4. Li, G.; Zhu, P. Structure and organization of chromatin fiber in the nucleus. FEBS Lett. 2015, 589, $2893-2904$. [CrossRef] [PubMed]

5. Ptashne, M. On the use of the word 'epigenetic'. Curr. Biol. 2007, 17, R233-R236. [CrossRef] 
6. Moore, L.D.; Le, T.; Fan, G. DNA methylation and its basic function. Neuropsychopharmacology 2013, 38, 23-38. [CrossRef] [PubMed]

7. Kornberg, R.D. Chromatin structure: A repeating unit of histones and DNA. Science 1974, 184, 868-871. [CrossRef] [PubMed]

8. Kornberg, R.D.; Lorch, Y. Twenty-five years of the nucleosome, fundamental particle of the eukaryote chromosome. Cell 1999, 98, 285-294. [CrossRef]

9. Bennett, R.L.; Licht, J.D. Targeting epigenetics in cancer. Annu. Rev. Pharmacol. Toxicol. 2018, 58, $187-207$. [CrossRef]

10. Yang, A.Y.; Kim, H.; Li, W.; Kong, A.N. Compound-derived epigenetic regulators targeting epigenetic readers, writers and erasers. Curr. Top. Med. Chem. 2016, 16, 697-713. [CrossRef]

11. Mio, C.; Bulotta, S.; Russo, D.; Damante, G. Reading cancer: Chromatin readers as druggable targets for cancer treatment. Cancers 2019, 11, 61. [CrossRef] [PubMed]

12. Shahbazian, M.D.; Grunstein, M. Functions of site-specific histone acetylation and deacetylation. Annu. Rev. Biochem. 2007, 76, 75-100. [CrossRef] [PubMed]

13. Haberland, M.; Montgomery, R.L.; Olson, E.N. The many roles of histone deacetylases in development and physiology. Nat. Rev. Genet 2009, 10, 32-42. [CrossRef] [PubMed]

14. Bannister, A.J.; Kouzarides, T. Regulation of chromatin by histone modifications. Cell Res. 2011, 21, $381-395$. [CrossRef]

15. Chen, H.; Tini, M.; Evans, R.M. HATS on and beyond chromatin. Curr. Opin. Cell Biol. 2001, 13, $218-224$. [CrossRef]

16. Biswas, S.; Rao, C.M. Epigenetic tools (The Writers, The Readers and The Erasers) and their implications in cancer therapy. Eur. J. Pharmacol. 2018, 837, 8-24. [CrossRef]

17. Fujisawa, T.; Filippakopoulos, P. Functions of bromodomain-containing proteins and their roles in homeostasis and cancer. Nat. Rev. Mol. Cell Biol. 2017, 18, 246-262. [CrossRef]

18. Filippakopoulos, P.; Picaud, S.; Mangos, M.; Keates, T.; Lambert, J.P.; Barsyte-Lovejoy, D.; Felletar, I.; Volkmer, R.; Müller, S.; Pawson, T.; et al. Histone recognition and large-scale structural analysis of the human bromodomain family. Cell 2012, 149, 214-231. [CrossRef]

19. Arrowsmith, C.H.; Bountra, C.; Fish, P.V.; Lee, K.; Schapira, M. Epigenetic protein families: A new frontier for drug discovery. Nat. Rev. Drug Discov. 2012, 11, 384-400. [CrossRef]

20. Hudson, B.P.; Martinez-Yamout, M.A.; Dyson, H.J.; Wright, P.E. Solution structure and acetyl-lysine binding activity of the GCN5 bromodomain. J. Mol. Biol. 2000, 304, 355-370. [CrossRef]

21. Dhalluin, C.; Carlson, J.E.; Zeng, L.; He, C.; Aggarwal, A.K.; Zhou, M.M. Structure and ligand of a histone acetyltransferase bromodomain. Nature 1999, 399, 491-496. [CrossRef] [PubMed]

22. Zeng, L.; Zhang, Q.; Gerona-Navarro, G.; Moshkina, N.; Zhou, M.M. Structural basis of site-specific histone recognition by the bromodomains of human coactivators PCAF and CBP/p300. Structure 2008, 16, 643-652. [CrossRef] [PubMed]

23. Nakamura, T.; Mori, T.; Tada, S.; Krajewski, W.; Rozovskaia, T.; Wassell, R.; Dubois, G.; Mazo, A.; Croce, C.M.; Canaani, E. ALL-1 is a histone methyltransferase that assembles a supercomplex of proteins involved in transcriptional regulation. Mol. Cell 2002, 10, 1119-1128. [CrossRef]

24. Zhu, L.; Li, Q.; Wong, S.H.; Huang, M.; Klein, B.J.; Shen, J.; Ikenouye, L.; Onishi, M.; Schneidawind, D.; Buechele, C.; et al. ASH1L Links Histone H3 Lysine 36 Dimethylation to MLL Leukemia. Cancer Discov. 2016, 6, 770-783. [CrossRef] [PubMed]

25. Zhao, X.; Su, J.; Wang, F.; Liu, D.; Ding, J.; Yang, Y.; Conaway, J.W.; Conaway, R.C.; Cao, L.; Wu, D.; et al. Crosstalk between NSL histone acetyltransferase and MLL/SET complexes: NSL complex functions in promoting histone H3K4 di-methylation activity by MLL/SET complexes. PLoS Genet 2013, 9, e1003940. [CrossRef] [PubMed]

26. Ewing, A.K.; Attner, M.; Chakravarti, D. Novel regulatory role for human Acf1 in transcriptional repression of vitamin D3 receptor-regulated genes. Mol. Endocrinol. 2007, 21, 1791-1806. [CrossRef] [PubMed]

27. Ruthenburg, A.J.; Li, H.; Milne, T.A.; Dewell, S.; McGinty, R.K.; Yuen, M.; Ueberheide, B.; Dou, Y.; Muir, T.W.; Patel, D.J.; et al. Recognition of a mononucleosomal histone modification pattern by BPTF via multivalent interactions. Cell 2011, 145, 692-706. [CrossRef]

28. LeRoy, G.; Rickards, B.; Flint, S.J. The double bromodomain proteins Brd2 and Brd3 couple histone acetylation to transcription. Mol. Cell 2008, 30, 51-60. [CrossRef] 
29. Wu, T.; Kamikawa, Y.F.; Donohoe, M.E. Brd4's bromodomains mediate histone H3 acetylation and chromatin remodeling in pluripotent cells through P300 and Brg1. Cell Rep. 2018, 25, 1756-1771. [CrossRef]

30. Morinière, J.; Rousseaux, S.; Steuerwald, U.; Soler-López, M.; Curtet, S.; Vitte, A.L.; Govin, J.; Gaucher, J.; Sadoul, K.; Hart, D.J.; et al. Cooperative binding of two acetylation marks on a histone tail by a single bromodomain. Nature 2009, 461, 664-668.

31. Fujiki, R.; Kim, M.S.; Sasaki, Y.; Yoshimura, K.; Kitagawa, H.; Kato, S. Ligand-induced transrepression by VDR through association of WSTF with acetylated histones. EMBO J. 2005, 24, 3881-3894. [CrossRef] [PubMed]

32. Couture, J.P.; Nolet, G.; Beaulieu, E.; Blouin, R.; Gévry, N. The p400/Brd8 chromatin remodeling complex promotes adipogenesis by incorporating histone variant H2A.Z at PPAR $\gamma$ target genes. Endocrinology 2012, 153, 5796-5808. [CrossRef] [PubMed]

33. Kalla, C.; Nentwich, H.; Schlotter, M.; Mertens, D.; Wildenberger, K.; Döhner, H.; Stilgenbauer, S.; Lichter, P. Translocation $\mathrm{t}(\mathrm{X} ; 11)(\mathrm{q} 13 ; \mathrm{q} 23)$ in B-cell chronic lymphocytic leukemia disrupts two novel genes. Genes Chromosomes Cancer 2005, 42, 128-143. [CrossRef] [PubMed]

34. Tropberger, P.; Pott, S.; Keller, C.; Kamieniarz-Gdula, K.; Caron, M.; Richter, F.; Li, G.; Mittler, G.; Liu, E.T.; Bühler, M.; et al. Regulation of transcription through acetylation of H3K122 on the lateral surface of the histone octamer. Cell 2013, 152, 859-872. [CrossRef]

35. Jin, Q.; Yu, L.R.; Wang, L.; Zhang, Z.; Kasper, L.H.; Lee, J.E.; Wang, C.; Brindle, P.K.; Dent, S.Y.; Ge, K. Distinct roles of GCN5/PCAF-mediated H3K9ac and CBP/p300-mediated H3K18/27ac in nuclear receptor transactivation. EMBO J. 2011, 30, 249-262. [CrossRef] [PubMed]

36. Podcheko, A.; Northcott, P.; Bikopoulos, G.; Lee, A.; Bommareddi, S.R.; Kushner, J.A.; Farhang-Fallah, J.; Rozakis-Adcock, M. Identification of a WD40 repeat-containing isoform of PHIP as a novel regulator of beta-cell growth and survival. Mol. Cell Biol. 2007, 27, 6484-6496. [CrossRef]

37. Huang, H.; Rambaldi, I.; Daniels, E.; Featherstone, M. Expression of the Wdr9 gene and protein products during mouse development. Dev. Dyn. 2003, 227, 608-614. [CrossRef]

38. Koo, S.J.; Fernandez-Montalvan, A.E.; Badock, V.; Ott, C.J.; Holton, S.J.; von Ahsen, O.; Toedling, J.; Vittori, S.; Bradner, J.E.; Gorjanacz, M. ATAD2 is an epigenetic reader of newly synthesized histone marks during DNA replication. Oncotarget 2016, 7, 70323-70335. [CrossRef]

39. Revenko, A.S.; Kalashnikova, E.V.; Gemo, A.T.; Zou, J.X.; Chen, H.W. Chromatin loading of E2F-MLL complex by cancer-associated coregulator ANCCA via reading a specific histone mark. Mol. Cell Biol. 2010, 30, 5260-5272. [CrossRef]

40. Mishima, Y.; Miyagi, S.; Saraya, A.; Negishi, M.; Endoh, M.; Endo, T.A.; Toyoda, T.; Shinga, J.; Katsumoto, T.; Chiba, T.; et al. The Hbo1-Brd1/Brpf2 complex is responsible for global acetylation of H3K14 and required for fetal liver erythropoiesis. Blood 2011, 118, 2443-2453. [CrossRef]

41. Sun, H.; Liu, J.; Zhang, J.; Shen, W.; Huang, H.; Xu, C.; Dai, H.; Wu, J.; Shi, Y. Solution structure of BRD7 bromodomain and its interaction with acetylated peptides from histone $\mathrm{H} 3$ and H4. Biochem. Biophys. Res. Commun. 2007, 358, 435-441. [CrossRef] [PubMed]

42. Flynn, E.M.; Huang, O.W.; Poy, F.; Oppikofer, M.; Bellon, S.F.; Tang, Y.; Cochran, A.G. A subset of human bromodomains recognizes butyryllysine and crotonyllysine histone peptide modifications. Structure 2015, 23, 1801-1814. [CrossRef] [PubMed]

43. Poplawski, A.; Hu, K.; Lee, W.; Natesan, S.; Peng, D.; Carlson, S.; Shi, X.; Balaz, S.; Markley, J.L.; Glass, K.C. Molecular insights into the recognition of N-terminal histone modifications by the BRPF1 bromodomain. J. Mol. Biol. 2014, 426, 1661-1676. [CrossRef] [PubMed]

44. Feng, Y.; Vlassis, A.; Roques, C.; Lalonde, M.E.; González-Aguilera, C.; Lambert, J.P.; Lee, S.B.; Zhao, X.; Alabert, C.; et al. BRPF3-HBO1 regulates replication origin activation and histone H3K14 acetylation. EMBO J. 2016, 35, 176-192. [CrossRef]

45. Zhou, Y.; Grummt, I. The PHD finger/bromodomain of NoRC interacts with acetylated histone H4K16 and is sufficient for rDNA silencing. Curr. Biol. 2005, 15, 1434-1438. [CrossRef]

46. Ferguson, F.M.; Dias, D.M.; Rodrigues, J.P.; Wienk, H.; Boelens, R.; Bonvin, A.M.; Abell, C.; Ciulli, A. Binding hotspots of BAZ2B bromodomain: Histone interaction revealed by solution NMR driven docking. Biochemistry 2014, 53, 6706-6716. [CrossRef] 
47. Seeler, J.S.; Marchio, A.; Sitterlin, D.; Transy, C.; Dejean, A. Interaction of SP100 with HP1 proteins: A link between the promyelocytic leukemia-associated nuclear bodies and the chromatin compartment. Proc. Natl. Acad. Sci. USA 1998, 95, 7316-7321. [CrossRef]

48. Bloch, D.B.; Nakajima, A.; Gulick, T.; Chiche, J.D.; Orth, D.; de La Monte, S.M.; Bloch, K.D. Sp110 localizes to the PML-Sp100 nuclear body and may function as a nuclear hormone receptor transcriptional coactivator. Mol. Cell Biol. 2000, 20, 6138-6146. [CrossRef]

49. Karaky, M.; Fedetz, M.; Potenciano, V.; Andrés-León, E.; Codina, A.E.; Barrionuevo, C.; Alcina, A.; Matesanz, F. SP140 regulates the expression of immune-related genes associated with multiple sclerosis and other autoimmune diseases by NF-KB inhibition. Hum. Mol. Genet 2018, 27, 4012-4023. [CrossRef]

50. Franke, A.; McGovern, D.P.; Barrett, J.C.; Wang, K.; Radford-Smith, G.L.; Ahmad, T.; Lees, C.W.; Balschun, T.; Lee, J.; et al. Genome-wide meta-analysis increases to 71 the number of confirmed Crohn's disease susceptibility loci. Nat. Genet 2010, 42, 1118-1125. [CrossRef]

51. Lv, D.; Li, Y.; Zhang, W.; Alvarez, A.A.; Song, L.; Tang, J.; Gao, W.Q.; Hu, B.; Cheng, S.Y.; Feng, H. TRIM24 is an oncogenic transcriptional co-activator of STAT3 in glioblastoma. Nat. Commun. 2017, 8, 1454. [CrossRef] [PubMed]

52. Agricola, E.; Randall, R.A.; Gaarenstroom, T.; Dupont, S.; Hill, C.S. Recruitment of TIF1gamma to chromatin via its PHD finger-bromodomain activates its ubiquitin ligase and transcriptional repressor activities. Mol. Cell 2011, 43, 85-96. [CrossRef] [PubMed]

53. Khetchoumian, K.; Teletin, M.; Mark, M.; Lerouge, T.; Cerviño, M.; Oulad-Abdelghani, M.; Chambon, P.; Losson, R. TIF1delta, a novel HP1-interacting member of the transcriptional intermediary factor 1 (TIF1) family expressed by elongating spermatids. J. Biol. Chem. 2004, 279, 48329-48341. [CrossRef] [PubMed]

54. Jacobson, R.H.; Ladurner, A.G.; King, D.S.; Tjian, R. Structure and function of a human TAFII250 double bromodomain module. Science 2000, 288, 1422-1425. [CrossRef]

55. Wang, P.J.; Page, D.C. Functional substitution for TAF(II)250 by a retroposed homolog that is expressed in human spermatogenesis. Hum. Mol. Genet 2002, 11, 2341-2346. [CrossRef]

56. Savitsky, P.; Krojer, T.; Fujisawa, T.; Lambert, J.P.; Picaud, S.; Wang, C.Y.; Shanle, E.K.; Krajewski, K.; Friedrichsen, H.; Kanapin, A.; et al. Multivalent Histone and DNA engagement by a PHD/BRD/PWWP triple reader cassette recruits ZMYND8 to K14ac-rich chromatin. Cell Rep. 2016, 17, 2724-2737. [CrossRef]

57. Wei, G.; Schaffner, A.E.; Baker, K.M.; Mansky, K.C.; Ostrowski, M.C. Ets-2 interacts with co-repressor BS69 to repress target gene expression. Anticancer Res. 2003, 23, 2173-2178.

58. Chandrasekaran, R.; Thompson, M. Polybromo-1-bromodomains bind histone H3 at specific acetyl-lysine positions. Biochem. Biophys. Res. Commun. 2007, 355, 661-666. [CrossRef]

59. Morrison, E.A.; Sanchez, J.C.; Ronan, J.L.; Farrell, D.P.; Varzavand, K.; Johnson, J.K.; Gu, B.X.p; Crabtree, G.R.; Musselman, C.A. DNA binding drives the association of BRG1/hBRM bromodomains with nucleosomes. Nat. Commun. 2017, 8, 16080. [CrossRef]

60. Pham, T.X.; Bae, M.; Lee, Y.; Park, Y.K.; Lee, J.Y. Transcriptional and posttranscriptional repression of histone deacetylases by docosahexaenoic acid in macrophages. J. Nutr. Biochem. 2018, 57, 162-169. [CrossRef]

61. Attar, N.; Kurdistani, S.K. Exploitation of EP300 and CREBBP lysine acetyltransferases by cancer. Cold Spring Harb. Perspect. Med. 2017, 7, a026534. [CrossRef] [PubMed]

62. Musco, G.; Peterson, P. PHD finger of autoimmune regulator: An epigenetic link between the histone modifications and tissue-specific antigen expression in thymus. Epigenetics 2008, 3, 310-314. [CrossRef] [PubMed]

63. Zhang, Y.; Jang, Y.; Lee, J.E.; Ahn, J.; Xu, L.; Holden, M.R.; Cornett, E.M.; Krajewski, K.; Klein, B.J.; Wang, S.P.; et al. Selective binding of the PHD6 finger of MLL4 to histone H4K16ac links MLL4 and MOF. Nat. Commun. 2019, 10, 2314. [CrossRef] [PubMed]

64. Sabari, B.R.; Zhang, D.; Allis, C.D.; Zhao, Y. Metabolic regulation of gene expression through histone acylations. Nat. Rev. Mol. Cell Biol. 2017, 18, 90-101. [CrossRef]

65. Qiu, Y.; Liu, L.; Zhao, C.; Han, C.; Li, F.; Zhang, J.; Wang, Y.; Li, G.; Mei, Y.; Wu, M.; et al. Combinatorial readout of unmodified H3R2 and acetylated $\mathrm{H} 3 \mathrm{~K} 14$ by the tandem PHD finger of MOZ reveals a regulatory mechanism for HOXA9 transcription. Genes Dev. 2012, 26, 1376-1391. [CrossRef]

66. Ali, M.; Yan, K.; Lalonde, M.E.; Degerny, C.; Rothbart, S.B.; Strahl, B.D.; Côté, J.; Yang, X.J.; Kutateladze, T.G. Tandem PHD fingers of MORF/MOZ acetyltransferases display selectivity for acetylated histone $\mathrm{H} 3$ and are required for the association with chromatin. J. Mol. Biol. 2012, 424, 328-338. [CrossRef] 
67. Huber, F.M.; Greenblatt, S.M.; Davenport, A.M.; Martinez, C.; Xu, Y.; Vu, L.P.; Nimer, S.D.; Hoelz, A. Histone-binding of DPF2 mediates its repressive role in myeloid differentiation. Proc. Natl. Acad. Sci. USA 2017, 114, 6016-6021. [CrossRef]

68. Lange, M.; Kaynak, B.; Forster, U.B.; Tönjes, M.; Fischer, J.J.; Grimm, C.; Schlesinger, J.; Just, S.; Dunkel, I.; Krueger, T.; et al. Regulation of muscle development by DPF3, a novel histone acetylation and methylation reader of the BAF chromatin remodeling complex. Genes Dev. 2008, 22, 2370-2384. [CrossRef]

69. Le, M.; Yu, D.Y.; Jensen, K.; Chevalier, A.; Courbeyrette, R.; Boulard, Y.; Smith, M.M.; Mann, C. Yaf9, a novel $\mathrm{NuA} 4$ histone acetyltransferase subunit, is required for the cellular response to spindle stress in yeast. Mol. Cell Biol. 2003, 23, 6086-6102.

70. Schulze, J.M.; Wang, A.Y.; Kobor, M.S. YEATS domain proteins: A diverse family with many links to chromatin modification and transcription. Biochem. Cell Biol. 2009, 87, 65-75. [CrossRef]

71. Daser, A.; Rabbitts, T.H. Extending the repertoire of the mixed-lineage leukemia gene MLL in leukemogenesis. Genes Dev. 2004, 18, 965-974. [CrossRef]

72. Li, Y.; Wen, H.; Xi, Y.; Tanaka, K.; Wang, H.; Peng, D.; Ren, Y.; Jin, Q.; Dent, S.Y.; Li, W.; et al. AF9 YEATS domain links histone acetylation to DOT1L-mediated H3K79 methylation. Cell 2014, 159, 558-571. [CrossRef]

73. Wan, L.; Wen, H.; Li, Y.; Lyu, J.; Xi, Y.; Hoshii, T.; Joseph, J.K.; Wang, X.; Loh, Y.E.; Erb, M.A.; et al. ENL links histone acetylation to oncogenic gene expression in acute myeloid leukaemia. Nature 2017, 543, 265-269. [CrossRef] [PubMed]

74. Cho, H.J.; Li, H.; Linhares, B.M.; Kim, E.; Ndoj, J.; Miao, H.; Grembecka, J.; Cierpicki, T. GAS41 recognizes di-acetylated histone $\mathrm{H} 3$ through a bivalent binding mode. ACS Chem. Biol. 2018, 13, 2739-2746. [CrossRef]

75. Shanle, E.K.; Andrews, F.H.; Meriesh, H.; McDaniel, S.L.; Dronamraju, R.; DiFiore, J.V.; Jha, D.; Wozniak, G.G.; Bridgers, J.B.; Kerschner, J.L.; et al. Association of Taf14 with acetylated histone H3 directs gene transcription and the DNA damage response. Genes Dev. 2015, 29, 1795-1800. [CrossRef]

76. Wang, A.Y.; Schulze, J.M.; Skordalakes, E.; Gin, J.W.; Berger, J.M.; Rine, J.; Kobor, M.S. Asf1-like structure of the conserved Yaf9 YEATS domain and role in H2A.Z deposition and acetylation. Proc. Natl. Acad. Sci. USA 2009, 106, 21573-21578. [CrossRef]

77. Musselman, C.A.; Lalonde, M.E.; Côté, J.; Kutateladze, T.G. Perceiving the epigenetic landscape through histone readers. Nat. Struct. Mol. Biol. 2012, 19, 1218-1227. [CrossRef]

78. Ball, L.J.; Murzina, N.V.; Broadhurst, R.W.; Raine, A.R.; Archer, S.J.; Stott, F.J.; Murzin, A.G.; Singh, P.B.; Domaille, P.J.; Laue, E.D. Structure of the chromatin binding (chromo) domain from mouse modifier protein 1. EMBO J. 1997, 16, 2473-2481. [CrossRef]

79. Yap, K.L.; Zhou, M.M. Keeping it in the family: Diverse histone recognition by conserved structural folds. Crit. Rev. Biochem. Mol. Biol. 2010, 45, 488-505. [CrossRef]

80. Eissenberg, J.C. Structural biology of the chromodomain: Form and function. Gene 2012, 496, 69-78. [CrossRef]

81. Kaustov, L.; Ouyang, H.; Amaya, M.; Lemak, A.; Nady, N.; Duan, S.; Wasney, G.A.; Li, Z.; Vedadi, M.; Schapira, M.; et al. Recognition and specificity determinants of the human Cbx chromodomain. J. Biol. Chem. 2011, 286, 521-529. [CrossRef] [PubMed]

82. Schalch, T.; Job, G.; Noffsinger, V.J.; Shanker, S.; Kuscu, C.; Joshua-Tor, L.; Partridge, J.F. High-affinity binding of Chp1 chromodomain to $\mathrm{K} 9$ methylated histone $\mathrm{H} 3$ is required to establish centromeric heterochromatin. Mol. Cell 2009, 34, 36-46. [CrossRef] [PubMed]

83. Sadaie, M.; Kawaguchi, R.; Ohtani, Y.; Arisaka, F.; Tanaka, K.; Shirahige, K.; Nakayama, J. Balance between distinct HP1 family proteins controls heterochromatin assembly in fission yeast. Mol. Cell Biol. 2008, 28, 6973-6988. [CrossRef] [PubMed]

84. Vermeulen, M.; Eberl, H.C.; Matarese, F.; Marks, H.; Denissov, S.; Butter, F.; Lee, K.K.; Olsen, J.V.; Hyman, A.; Stunnenberg, H.G.; et al. Quantitative interaction proteomics and genome-wide profiling of epigenetic histone marks and their readers. Cell 2010, 142, 967-980. [CrossRef] [PubMed]

85. Bernstein, E.; Duncan, E.M.; Masui, O.; Gil, J.; Heard, E.; Allis, C.D. Mouse polycomb proteins bind differentially to methylated histone $\mathrm{H} 3$ and RNA and are enriched in facultative heterochromatin. Mol. Cell Biol. 2006, 26, 2560-2569. [CrossRef] [PubMed]

86. Larschan, E.; Alekseyenko, A.A.; Gortchakov, A.A.; Peng, S.; Li, B.; Yang, P.; Workman, J.L.; Park, P.J.; Kuroda, M.I. MSL complex is attracted to genes marked by H3K36 trimethylation using a sequence-independent mechanism. Mol. Cell 2007, 28, 121-133. [CrossRef] 
87. Kim, D.; Blus, B.J.; Chandra, V.; Huang, P.; Rastinejad, F.; Khorasanizadeh, S. Corecognition of DNA and a methylated histone tail by the MSL3 chromodomain. Nat. Struct. Mol. Biol. 2010, 17, 1027-1029. [CrossRef]

88. Zhang, P.; Du, J.; Sun, B.; Dong, X.; Xu, G.; Zhou, J.; Huang, Q.; Liu, Q.; Hao, Q.; Ding, J. Structure of human MRG15 chromo domain and its binding to Lys36-methylated histone H3. Nucl. Acids. Res. 2006, 34, 6621-6628. [CrossRef]

89. Joshi, A.A.; Struhl, K. Eaf3 chromodomain interaction with methylated H3-K36 links histone deacetylation to Pol II elongation. Mol. Cell 2005, 20,971-978. [CrossRef]

90. Flanagan, J.F.; Mi, L.Z.; Chruszcz, M.; Cymborowski, M.; Clines, K.L.; Kim, Y.; Minor, W.; Rastinejad, F.; Khorasanizadeh, $\mathrm{S}$. Double chromodomains cooperate to recognize the methylated histone H3 tail. Nature 2005, 438, 1181-1185. [CrossRef]

91. Sims, R.J., 3rd; Millhouse, S.; Chen, C.F.; Lewis, B.A.; Erdjument-Bromage, H.; Tempst, P.; Manley, J.L.; Reinberg, D. Recognition of trimethylated histone H3 lysine 4 facilitates the recruitment of transcription postinitiation factors and pre-mRNA splicing. Mol. Cell 2007, 28, 665-676. [CrossRef] [PubMed]

92. Sims, R.J., 3rd; Chen, C.F.; Santos-Rosa, H.; Kouzarides, T.; Patel, S.S.; Reinberg, D. Human but not yeast CHD1 binds directly and selectively to histone $\mathrm{H} 3$ methylated at lysine 4 via its tandem chromodomains. J. Biol. Chem. 2005, 280, 41789-41792. [CrossRef] [PubMed]

93. Schnetz, M.P.; Bartels, C.F.; Shastri, K.; Balasubramanian, D.; Zentner, G.E.; Balaji, R.; Zhang, X.; Song, L.; Wang, Z.; Laframboise, T.; et al. Genomic distribution of CHD7 on chromatin tracks H3K4 methylation patterns. Genome Res. 2009, 19, 590-601. [CrossRef] [PubMed]

94. Kim, J.; Daniel, J.; Espejo, A.; Lake, A.; Krishna, M.; Xia, L.; Zhang, Y.; Bedford, M.T. Tudor, MBT and chromo domains gauge the degree of lysine methylation. EMBO Rep. 2006, 7, 397-403. [CrossRef]

95. Machev, N.; Saut, N.; Longepied, G.; Terriou, P.; Navarro, A.; Levy, N.; Guichaoua, M.; Metzler-Guillemain, C.; Collignon, P.; Frances, A.M.; et al. Sequence family variant loss from the AZFc interval of the human $\mathrm{Y}$ chromosome, but not gene copy loss, is strongly associated with male infertility. J. Med. Genet 2004, 41, 814-825. [CrossRef]

96. Franz, H.; Mosch, K.; Soeroes, S.; Urlaub, H.; Fischle, W. Multimerization and H3K9me3 binding are required for CDYL1b heterochromatin association. J. Biol. Chem. 2009, 284, 35049-35059. [CrossRef]

97. Escamilla-Del-Arenal, M.; da Rocha, S.T.; Spruijt, C.G.; Masui, O.; Renaud, O.; Smits, A.H.; Margueron, R.; Vermeulen, M.; Heard, E. Cdyl, a new partner of the inactive $X$ chromosome and potential reader of H3K27me3 and H3K9me2. Mol. Cell Biol. 2013, 33, 5005-5020. [CrossRef]

98. Vermeulen, M.; Mulder, K.W.; Denissov, S.; Pijnappel, W.W.; van Schaik, F.M.; Varier, R.A.; Baltissen, M.P.; Stunnenberg, H.G.; Mann, M.; Timmers, H.T. Selective anchoring of TFIID to nucleosomes by trimethylation of histone H3 lysine 4. Cell 2007, 131, 58-69. [CrossRef]

99. Klein, B.J.; Wang, X.; Cui, G.; Yuan, C.; Botuyan, M.V.; Lin, K.; Lu, Y.; Wang, X.; Zhao, Y.; Bruns, C.J.; et al. PHF20 readers link methylation of histone H3K4 and p53 with H4K16 acetylation. Cell Rep. 2016, 17, 1158-1170. [CrossRef]

100. Ali, M.; Rincón-Arano, H.; Zhao, W.; Rothbart, S.B.; Tong, Q.; Parkhurst, S.M.; Strahl, B.D.; Deng, L.W.; Groudine, M.; Kutateladze, T.G. Molecular basis for chromatin binding and regulation of MLL5. Proc. Natl. Acad. Sci. USA 2013, 110, 11296-11301. [CrossRef]

101. Xie, S.; Jakoncic, J.; Qian, C. UHRF1 double Tudor domain and the adjacent PHD finger act together to recognize K9me3-containing histone H3 tail. J. Mol. Biol. 2012, 415, 318-328. [CrossRef] [PubMed]

102. Mansfield, R.E.; Musselman, C.A.; Kwan, A.H.; Oliver, S.S.; Garske, A.L.; Davrazou, F.; Denu, J.M.; Kutateladze, T.G.; Mackay, J.P. Plant homeodomain (PHD) fingers of CHD4 are histone H3-binding modules with preference for unmodified H3K4 and methylated H3K9. J. Biol. Chem. 2011, 286, 1779-11791. [CrossRef] [PubMed]

103. Horton, J.R.; Upadhyay, A.K.; Qi, H.H.; Zhang, X.; Shi, Y.; Cheng, X. Enzymatic and structural insights for substrate specificity of a family of jumonji histone lysine demethylases. Nat. Struct. Mol. Biol. 2010, 17, 38-43. [CrossRef] [PubMed]

104. Pek, J.W.; Anand, A.; Kai, T. Tudor domain proteins in development. Development 2012, 139, $2255-2266$. [CrossRef]

105. Musselman, C.A.; Avvakumov, N.; Watanabe, R.; Abraham, CG.; Lalonde, M.E.; Hong, Z.; Allen, C.; Roy, S.; Nuñez, J.K.; Nickoloff, J.; et al. Molecular basis for H3K36me3 recognition by the Tudor domain of PHF1. Nat. Struct. Mol. Biol. 2012, 19, 1266-1272. [CrossRef] 
106. Ballaré, C.; Lange, M.; Lapinaite, A.; Martin, GM.; Morey, L.; Pascual, G.; Liefke, R.; Simon, B.; Shi, Y.; Gozani, O.; et al. Phf19 links methylated Lys36 of histone H3 to regulation of Polycomb activity. Nat. Struct. Mol. Biol. 2012, 19, 1257-1265. [CrossRef]

107. Cai, L.; Rothbart, S.B.; Lu, R.; Xu, B.; Chen, W.Y.; Tripathy, A.; Rockowitz, S.; Zheng, D.; Patel, D.J.; Allis, C.D.; et al. An H3K36 methylation-engaging Tudor motif of polycomb-like proteins mediates PRC2 complex targeting. Mol. Cell 2013, 49, 571-582. [CrossRef]

108. Weaver, T.M.; Morrison, E.A.; Musselman, C.A. Reading more than histones: The prevalence of nucleic acid binding among reader domains. Molecules 2018, 23, 2614. [CrossRef]

109. Shi, Y.; Whetstine, J.R. Dynamic Regulation of Histone Lysine Methylation by Demethylases. Mol. Cell 2007, 25, 1-14. [CrossRef]

110. Lee, J.; Thompson, J.R.; Botuyan, M.V.; Mer, G. Distinct binding modes specify the recognition of methylated histones H3K4 and H4K20 by JMJD2A-tudor. Nat. Struct. Mol. Biol. 2008, 15, 109-111. [CrossRef]

111. Huang, Y.; Fang, J.; Bedford, M.T.; Zhang, Y.; Xu, R.M. Recognition of histone H3 lysine-4 methylation by the double tudor domain of JMJD2A. Science 2006, 312, 748-751. [CrossRef]

112. Lu, R.; Wang, G.G. Tudor: A versatile family of histone methylation 'readers'. Trends Biochem. Sci. 2013, 38, 546-555. [CrossRef] [PubMed]

113. Botuyan, M.V.; Lee, J.; Ward, I.M.; Kim, J.E.; Thompson, J.R.; Chen, J.; Mer, G. Structural basis for the methylation state-specific recognition of histone H4-K20 by 53BP1 and Crb2 in DNA repair. Cell 2006, 127, 1361-1373. [CrossRef] [PubMed]

114. Wu, H.; Zeng, H.; Lam, R.; Tempel, W.; Amaya, M.F.; Xu, C.; Dombrovski, L.; Qiu, W.; Wang, Y.; Min, J. Structural and histone binding ability characterizations of human PWWP domains. PLoS ONE 2011, 6, e18919. [CrossRef] [PubMed]

115. Wang, R.; Gao, J.; Zhang, J.; Zhang, X.; Xu, C.; Liao, S.; Tu, X. Solution structure of TbTFIIS2-2 PWWP domain from Trypanosoma brucei and its binding to H4K17me3 and H3K32me3. Biochem. J. 2019, 476, 421-431. [CrossRef]

116. Pradeepa, M.M.; Sutherland, H.G.; Ule, J.; Grimes, G.R.; Bickmore, W.A. Psip1/Ledgf p52 binds methylated histone $\mathrm{H} 3 \mathrm{~K} 36$ and splicing factors and contributes to the regulation of alternative splicing. PLoS Genet 2012, 8, e1002717. [CrossRef]

117. Guo, R.; Zheng, L.J.; Park, J.W.; Lv, R.; Chen, H.; Jiao, F.; Xu, W.; Mu, S.; Wen, H.; Qiu, J.; et al. BS69/ZMYND11 reads and connects histone $\mathrm{H} 3.3$ lysine 36 trimethylation-decorated chromatin to regulated pre-mRNA processing. Mol. Cell 2014, 56, 298-310. [CrossRef]

118. Cermáková, K.; Tesina, P.; Demeulemeester, J.; EI, A.S.; Méreau, H.; Schwaller, J.; Rezáčová, P.; Veverka, V.; De Rijck, J. Validation and structural characterization of the LEDGF/p75-MLL interface as a new target for the treatment of MLL-dependent leukemia. Cancer Res. 2014, 74, 5139-5151.

119. Tesina, P.; Čermáková, K.; Hořejší, M.; Procházková, K.; Fábry, M.; Sharma, S.; Christ, F.; Demeulemeester, J.; Debyser, Z.; Rijck, J.; et al. Multiple cellular proteins interact with LEDGF/p75 through a conserved unstructured consensus motif. Nat. Commun. 2015, 6, 7968. [CrossRef]

120. Sharma, S.; Čermáková, K.; De, R.J.; Demeulemeester, J.; Fábry, M.; El, A.S.; Van, B.S.; Lepšík, M.; Tesina, P.; Duchoslav, V.; et al. Affinity switching of the LEDGF/p75 IBD interactome is governed by kinase-dependent phosphorylation. Proc. Natl. Acad. Sci. USA 2018, 115, 7053-7062. [CrossRef]

121. Gilbert, T.M.; McDaniel, S.L.; Byrum, S.D.; Cades, J.A.; Dancy, B.C.; Wade, H.; Tackett, A.J.; Strahl, B.D.; Taverna, S.D. A PWWP domain-containing protein targets the NuA3 acetyltransferase complex via histone $\mathrm{H} 3$ lysine 36 trimethylation to coordinate transcriptional elongation at coding regions. Mol. Cell Proteomics 2014, 13, 2883-2895. [CrossRef] [PubMed]

122. Wang, Y.; Reddy, B.; Thompson, J.; Wang, H.; Noma, K.; Yates, J.R., 3rd; Jia, S. Regulation of Set9-mediated H4K20 methylation by a PWWP domain protein. Mol. Cell 2009, 33, 428-437. [CrossRef] [PubMed]

123. Sendžikaitė, G.; Hanna, C.W.; Stewart-Morgan, K.R.; Ivanova, E.; Kelsey, G. A DNMT3A PWWP mutation leads to methylation of bivalent chromatin and growth retardation in mice. Nat. Commun. 2019, 10, 1884. [CrossRef] [PubMed]

124. Qiu, Y.; Zhang, W.; Zhao, C.; Wang, Y.; Wang, W.; Zhang, J.; Zhang, Z.; Li, G.; Shi, Y.; Tu, X.; et al. Solution structure of the Pdp1 PWWP domain reveals its unique binding sites for methylated H4K20 and DNA. Biochem. J. 2012, 442, 527-538. [CrossRef] 
125. Tian, W.; Yan, P.; Xu, N.; Chakravorty, A.; Liefke, R.; Xi, Q.; Wang, Z. The HRP3 PWWP domain recognizes the minor groove of double-stranded DNA and recruits HRP3 to chromatin. Nucl. Acids. Res. 2019, 47, 5436-5448. [CrossRef]

126. Schapira, M.; Tyers, M.; Torrent, M.; Arrowsmith, C.H. WD-repeat domain proteins: A novel target class. Nat. Rev. Drug Discov. 2017, 16, 773-786. [CrossRef]

127. Margueron, R.; Justin, N.; Ohno, K.; Sharpe, M.L.; Son, J.; Drury, W.J., 3rd. Role of the polycomb protein Eed in the propagation of repressive histone marks. Nature 2009, 461, 762-767. [CrossRef]

128. Wysocka, J.; Swigut, T.; Milne, T.A.; Dou, Y.; Zhang, X.; Burlingame, A.L.; Roeder, R.G.; Brivanlou, A.H.; Allis, C.D. WDR5 associates with histone $\mathrm{H} 3$ methylated at $\mathrm{K} 4$ and is essential for H3 K4 methylation and vertebrate development. Cell 2005, 121, 859-872. [CrossRef]

129. Ruthenburg, A.J.; Wang, W.; Graybosch, D.M.; Li, H.; Allis, C.D.; Patel, D.J.; Verdine, G.L. Histone H3 recognition and presentation by the WDR5 module of the MLL1 complex. Nat. Struct. Mol. Biol. 2006, 13, 704-712. [CrossRef]

130. Bonasio, R.; Lecona, E.; Reinberg, D. MBT domain proteins in development and disease. Semin. Cell Dev. Biol. 2010, 21, 221-230. [CrossRef]

131. Li, H.; Fischle, W.; Wang, W.; Duncan, E.M.; Liang, L.; Murakami-Ishibe, S.; Allis, C.D.; Patel, D.J. Structural basis for lower lysine methylation state-specific readout by MBT repeats of L3MBTL1 and an engineered PHD finger. Mol. Cell 2007, 28, 677-691. [CrossRef] [PubMed]

132. Klymenko, T.; Papp, B.; Fischle, W.; Köcher, T.; Schelder, M.; Fritsch, C.; Wild, B.; Wilm, M.; Müller, J. A polycomb group protein complex with sequence-specific DNA-binding and selective methyl-lysine-binding activities. Genes Dev. 2006, 20, 1110-1122. [CrossRef] [PubMed]

133. Tang, M.; Shen, H.; Jin, Y.; Lin, T.; Cai, Q.; Pinard, M.A.; Biswas, S.; Tran, Q.; Li, G.; Shenoy, A.K.; et al. The malignant brain tumor (MBT) domain protein SFMBT1 is an integral histone reader subunit of the LSD1 demethylase complex for chromatin association and epithelial-to-mesenchymal transition. J. Biol. Chem. 2013, 288, 27680-27691. [CrossRef] [PubMed]

134. Koester-Eiserfunke, N.; Fischle, W. H3K9me2/3 binding of the MBT domain protein LIN-61 is essential for caenorhabditis elegans vulva development. PLoS Genet 2011, 7, e1002017. [CrossRef]

135. Waldmann, T.; Schneider, R. Targeting histone modifications-epigenetics in cancer. Curr. Opin. Cell Biol. 2013, 25, 184-189. [CrossRef]

136. Cermakova, K.; Hodges, H.C. Next-generation drugs and probes for chromatin biology: From targeted protein degradation to phase separation. Molecules 2018, 23, 1958. [CrossRef]

137. Romero, F.A.; Taylor, A.M.; Crawford, T.D.; Tsui, V.; Côté, A.; Magnuson, S. Disrupting acetyl-lysine recognition: Progress in the development of bromodomain inhibitors. J. Med. Chem. 2016, 59, 1271-1298. [CrossRef]

138. Prinjha, R.K.; Witherington, J.; Lee, K. Place your BETs: The therapeutic potential of bromodomains. Trends Pharmacol. Sci. 2012, 33, 146-153. [CrossRef]

139. Delmore, J.E.; Issa, G.C.; Lemieux, M.E.; Rahl, P.B.; Shi, J.; Jacobs, H.M.; Kastritis, E.; Gilpatrick, T.; Paranal, RM.; Qi, J.; et al. BET bromodomain inhibition as a therapeutic strategy to target c-Myc. Cell 2011, 146, 904-917. [CrossRef]

140. Zuber, J.; Shi, J.; Wang, E.; Rappaport, AR.; Herrmann, H.; Sison, E.A.; Magoon, D.; Qi, J.; Blatt, K.; Wunderlich, M.; et al. RNAi screen identifies Brd4 as a therapeutic target in acute myeloid leukaemia. Nature 2011, 478, 524-528. [CrossRef]

141. Puissant, A.; Frumm, S.M.; Alexe, G.; Bassil,C.F.; Qi, J.; Chanthery, Y.H.; Nekritz, EA.; Zeid, R.; Gustafson, W.C.; Greninger, P.; et al. Targeting MYCN in neuroblastoma by BET bromodomain inhibition. Cancer Discov. 2013, 3, 308-323. [CrossRef] [PubMed]

142. Lockwood, W.W.; Zejnullahu, K.; Bradner, J.E.; Varmus, H. Sensitivity of human lung adenocar- cinoma cell lines to targeted inhibition of BET epigenetic signaling proteins. Proc. Natl. Acad. Sci. USA 2012, 109, 19408-19413. [CrossRef] [PubMed]

143. Garcia, P.L.; Miller, A.L.; Kreitzburg, K.M.; Council, L.N.; Gamblin, T.L.; Christei, J.D.; Heslin, M.J.; Arnoletti, J.P.; Richardson, J.H.; Chen, D.; et al. The BET bromodomain inhibitor JQ1 suppresses growth of pancreatic ductal adenocarcinoma in patient-derived xenograft models. Oncogene 2016, 35, 833-845. [CrossRef] [PubMed] 
144. Chaidos, A.; Caputo, V.; Gouvedenou, K.; Liu, B.; Marigo, I.; Chaudhry, M.S.; Rotolo, A.; Tough, D.F.; Smithers, N.N.; Bassil, A.K.; et al. Potent antimyeloma activity of the novel bromodomain inhibitors I-BET151 and I-BET762. Blood 2014, 123, 697-705. [CrossRef]

145. Berenguer-Daize, C.; Astorgues-Xerri, L.; Odore, E.; Cayol, M.; Cvitkovic, E.; Noel, K.; Bekradda, M.; MacKenzie, S.; Rezai, K.; Lokiec, F.; et al. OTX015 (MK-8628), a novel BET inhibitor, displays in vitro and in vivo antitumor effects alone and in combination with conventional therapies in glioblastoma models. Int. J. Cancer 2016, 139, 2047-2055. [CrossRef]

146. Picaud, S.; Da, C.D.; Thanasopoulou, A.; Filippakopoulos, P.; Fish, P.V.; Philpott, M.; Fedorov, O.; Brennan, P.; Bunnage, M.E.; Owen, D.R.; et al. PFI-1, a highly selective protein interaction inhibitor, targeting BET bromodomains. Cancer Res. 2013, 73, 3336-3346. [CrossRef]

147. Wadhwa, E.; Nicolaides, T. Bromodomain inhibitor review: Bromodomain and extra-terminal family protein inhibitors as a potential new therapy in central nervous system tumors. Cureus 2016, 8, e620. [CrossRef]

148. Cheng, X.; Huang, Z.; Long, D.; Jin, W. BET inhibitor bromosporine enhances 5-FU effect in colorectal cancer cells. Biochem. Biophys. Res. Commun. 2020, 521, 840-845. [CrossRef]

149. Pérez-Salvia, M.; Esteller, M. Bromodomain inhibitors and cancer therapy: From structures to applications. Epigenetics 2017, 12, 323-339. [CrossRef]

150. Albrecht, B.K.; Gehling, V.S.; Hewitt, M.C.; Vaswani, R.G.; Cote, A.; Leblanc, Y.; Nasveschuk, C.G.; Bellon, S.; Bergeron, L.; Campbell, R.; et al. Identification of a benzoisoxazoloazepine inhibitor (CPI-0610) of the bromodomain and extra-terminal (BET) family as a candidate for human clinical trials. J. Med. Chem. 2016, 59, 1330-1339. [CrossRef]

151. Rvx 208. Available online: https://www.ncbi.nlm.nih.gov/pmc/articles/PMC3585949/ (accessed on 10 September 2019).

152. Nicholls, S.J.; Puri, R.; Wolski, K.; Ballantyne, C.M.; Barter, P.J.; Brewer, H.B.; Kastelein, J.J.; Hu, B.; Uno, K.; Kataoka, Y.; et al. Effect of the BET protein inhibitor, RVX-208, on progression of coronary atherosclerosis: Results of the phase 2b, randomized, double-blind, multicenter, ASSURE trial. Am. J. Cardiovasc. Drugs 2016, 16, 55-65. [CrossRef] [PubMed]

153. ClinicalTrials.gov. Available online: https://clinicaltrials.gov (accessed on 9 November 2016).

154. Filippakopoulos, P.; Qi, J.; Picaud, S.; Shen, Y.; Smith, W.B.; Fedorov, O.; Morse, E.M.; Keates, T.; Hickman, T.T.; Felletar, I.; et al. Selective inhibition of BET bromodomains. Nature 2010, 468, 1067-1073. [CrossRef] [PubMed]

155. Theodoulou, N.H.; Bamborough, P.; Bannister, A.J.; Becher, I.; Bit, R.A.; Che, K.H.; Chung, C.W.; Dittmann, A.; Drewes, G.; Drewry, DH.; et al. Discovery of I-BRD9, a selective cell active chemical probe for bromodomain containing protein 9 inhibition. J. Med. Chem. 2016, 59, 1425-1439. [CrossRef]

156. Martin, L.J.; Koegl, M.; Bader, G.; Cockcroft, X.L.; Fedorov, O.; Fiegen, D.; Gerstberger, T.; Hofmann, M.H.; Hohmann, A.F.; Kessler, D.; et al. Structure-based design of an in vivo active selective BRD9 inhibitor. J. Med. Chem. 2016, 59, 4462-4475. [CrossRef]

157. Hohmann, A.F.; Martin, L.J.; Minder, J.L.; Roe, J.S.; Shi, J.; Steurer, S.; Bader, G.; McConnell, D.; Pearson, M.; Gerstberger, T.; et al. Sensitivity and engineered resistance of myeloid leukemia cells to BRD9 inhibition. Nat. Chem. Biol. 2016, 12, 672-679. [CrossRef]

158. Sachchidanand; Resnick-Silverman, L.; Yan, S.; Mutjaba, S.; Liu, W.J.; Zeng, L.; Manfredi, J.J.; Zhou, M.M. Target structure-based discovery of small molecules that block human p53 and CREB binding protein association. Chem. Biol. 2006, 13, 81-90. [CrossRef]

159. Chekler, E.L.; Pellegrino, J.A.; Lanz, T.A.; Denny, R.A.; Flick, A.C.; Coe, J.; Langille, J.; Basak, A.; Liu, S.; Stock, IA.; et al. Transcriptional profiling of a selective CREB binding protein bromodomain inhibitor highlights therapeutic opportunities. Chem. Biol. 2015, 22, 1588-1596. [CrossRef]

160. Picaud, S.; Fedorov, O.; Thanasopoulou, A.; Leonards, K.; Jones, K.; Meier, J.; Olzscha, H.; Monteiro, O.; Martin, S.; Philpott, M.; et al. Generation of a selective small molecule inhibitor of the CBP/p300 bromodomain for leukemia therapy. Cancer Res. 2015, 75, 5106-5119. [CrossRef]

161. Pegg, N.; Brooks, N.; Worthington, J.; Young, B.; Prosser, A.; Lane, J.; Taddei, D.; Brown, R.; Harbottle, G.; Shannon, J.; et al. Characterisation of CCS1477: A novel small molecule inhibitor of p300/CBP for the treatment of castration resistant prostate cancer [abstract]. J. Clin. Oncol. 2017, 35 (Suppl. S15), 11590. [CrossRef] 
162. Sanchez, R.; Zhou, M.M. The PHD finger: A versatile epigenome reader. Trends Biochem. Sci. 2011, 36, 364-372. [CrossRef]

163. Taverna, S.D.; Li, H.; Ruthenburg, A.J.; Allis, C.D.; Patel, D.J. How chromatin-binding modules interpret histone modifications: Lessons from professional pocket pickers. Nat. Struct. Mol. Biol. 2007, 14, 1025-1040. [CrossRef]

164. Milosevich, N.; Hof, F. Chemical inhibitors of epigenetic methyllysine reader proteins. Biochemistry 2016, 55, 1570-1583. [CrossRef]

165. Milosevich, N.; Gignac, M.C.; McFarlane, J.; Simhadri, C.; Horvath, S.; Daze, K.D.; Croft, C.S.; Dheri, A.; Quon, T.T.; Douglas, S.F.; et al. Selective inhibition of CBX6: A methyllysine reader protein in the Polycomb family. ACS Med. Chem. Lett. 2015, 7, 139-144. [CrossRef] [PubMed]

166. Ali, M.; Daze, K.D.; Strongin, D.E.; Rothbart, S.B.; Rincon-Arano, H.; Allen, H.F.; Li, J.; Strahl, B.D.; Hof, F.; Kutateladze, T.G. Molecular insights into inhibition of the methylated histone-plant homeodomain complexes by calixarenes. J. Biol. Chem. 2015, 290, 22919-22930. [CrossRef] [PubMed]

167. Wagner, E.K.; Nath, N.; Flemming, R.; Feltenberger, J.B.; Denu, J.M. Identification and characterization of small molecule inhibitors of a plant homeodomain finger. Biochemistry 2012, 51, 8293-8306. [CrossRef] [PubMed]

168. Miller, T.C.; Rutherford, T.J.; Birchall, K.; Chugh, J.; Fiedler, M.; Bienz, M. Competitive binding of a benzimidazole to the histone-binding pocket of the Pygo PHD finger. ACS Chem. Biol. 2014, 9, 2864-2874. [CrossRef] [PubMed]

169. Addou-Klouche, L.; Adélaïde, J.; Finetti, P.; Cervera, N.; Ferrari, A.; Bekhouche, I.; Sircoulomb, F.; Sotiriou, C.; Viens, P.; Moulessehoul, S.; et al. Loss, mutation and deregulation of L3MBTL4 in breast cancers. Mol. Cancer 2010, 9, 213. [CrossRef]

170. Herold, J.M.; Wigle, T.J.; Norris, J.L.; Lam, R.; Korboukh, V.K.; Gao., C.; Ingerman, L.A.; Kireev, D.B.; Senisterra, G.; Vedadi, M.; et al. Small-molecule ligands of methyl-lysine binding proteins. J. Med. Chem. 2011, 54, 2504-2511. [CrossRef]

171. Zhou, H.; Che, X.; Bao, G.; Wang, N.; Peng, L.; Barnash, K.D.; Frye, S.V.; James, L.I.; Bai, X. Design, synthesis, and protein methyltransferase activity of a unique set of constrained amine containing compounds. Bioorg. Med. Chem. Lett. 2016, 26, 4436-4440. [CrossRef]

172. James, L.I.; Barsyte-Lovejoy, D.; Zhong, N.; Krichevsky, L.; Korboukh, V.K.; Herold, J.M.; MacNevin, C.J.; Norris, J.L.; Sagum, C.A.; Tempel, W.; et al. Discovery of a chemical probe for the L3MBTL3 methyllysine reader domain. Nat. Chem. Biol. 2013, 9, 184-191. [CrossRef]

173. Perfetti, M.T.; Baughman, B.M.; Dickson, B.M.; Mu, Y.; Cui, G.; Mader, P.; Dong, A.; Norris, J.L.; Rothbart, S.B.; Strahl, B.D.; et al. Identification of a fragment-like small molecule ligand for the methyl-lysine binding protein, 53BP1. ACS Chem. Biol. 2015, 10, 1072-1081. [CrossRef] [PubMed]

174. Roatsch, M.; Hoffmann, I.; Abboud, M.I.; Hancock, R.L.; Tarhonskaya, H.; Hsu, K.F.; Wilkins, S.E.; Yeh, T.L.; Lippl, K.; Serrer, K.; et al. The clinically used iron chelator deferasirox is an inhibitor of epigenetic jumonjiC domain-containing histone demethylases. ACS Chem. Biol. 2019, 14, 1737-1750. [CrossRef] [PubMed]

175. Baylin, S.B. DNA methylation and gene silencing in cancer. Nat. Clin. Pract. Oncol. 2005, 2 (Suppl. S1), S4-11. [CrossRef] [PubMed]

176. Klauke, K.; Radulović, V.; Broekhuis, M.; Weersing, E.; Zwart, E.; Olthof, S.; Ritsema, M.; Bruggeman, S.; $\mathrm{Wu}$, X.; Helin, K.; et al. Polycomb Cbx Family Members Mediate the Balance between Haematopoietic Stem Cell Self-Renewal and Differentiation. Nat. Cell Biol. 2013, 15, 353-362. [CrossRef]

177. Morey, L.; Pascual, G.; Cozzuto, L.; Roma, G.; Wutz, A.; Benitah, S.A.; Di Croce, L. Nonoverlapping Functions of the Polycomb Group Cbx Family of Proteins in Embryonic Stem Cells. Cell Stem. Cell 2012, 10, 47-62. [CrossRef]

178. Zhang, C.Z.; Chen, S.L.; Wang, C.H.; He, Y.F.; Yang, X.; Xie, D.; Yun, J.P. CBX8 exhibits oncogenic activity via $\mathrm{AKT} / \mathrm{b}-$ Catenin activation in hepatocellular carcinoma. Cancer Res. 2017, 78, 51-63. [CrossRef]

179. Chung, C.Y.; Sun, Z.; Mullokandov, G.; Bosch, A.; Qadeer, Z.A.; Cihan, E.; Rapp, Z.; Parsons, R.; Aguirre-Ghiso, J.A.; Farias, E.F.; et al. Cbx8 acts non-canonically with Wdr5 to promote mammary tumorigenesis. Cell Rep. 2016, 16, 472-486. [CrossRef]

180. Tan, J.; Jones, M.; Koseki, H.; Nakayama, M.; Muntean, A.G.; Maillard, I.; Hess, J.L. CBX8, a polycomb group protein, is essential for MLL-AF9-induced leukemogenesis. Cancer Cell 2012, 20, 563-575. [CrossRef] 
181. Ren, C.; Morohashi, K.; Plotnikov, A.N.; Jakoncic, J.; Smith, S.G.; Li, J.; Zeng, L.; Rodriguez, Y.; Stojanoff, V.; Walsh, M.; et al. Small-molecule modulators of methyl-lysine binding for the CBX7 chromodomain. Chem. Biol. 2015, 22, 161-168. [CrossRef]

182. Wang, S.; Denton, K.E.; Hobbs, K.F.; Weaver, T.; McFarlane, J.M.B.; Connelly, K.E.; Gignac, M.C.; Milosevich, N.; Hof, F.; Paci, I.; et al. Optimization of ligands using focused DNA-encoded libraries to develop a selective, cell-permeable CBX8 chromodomain inhibitor. ACS Chem. Biol. 2020, 15, 112-131. [CrossRef]

183. Stuckey, J.I.; Dickson, B.M.; Cheng, N.; Liu, Y.; Norris, J.L.; Cholensky, S.H.; Tempel, W.; Qin, S.; Huber, K.G.; Sagum, C.; et al. A cellular chemical probe targeting the chromodomains of Polycomb repressive complex 1. Nat. Chem. Biol. 2016, 12, 180-187. [CrossRef] [PubMed]

(C) 2020 by the authors. Licensee MDPI, Basel, Switzerland. This article is an open access article distributed under the terms and conditions of the Creative Commons Attribution (CC BY) license (http://creativecommons.org/licenses/by/4.0/). 